\title{
Seasonal Intake and Digestibility of Natural Foods: by Roe-deer
}

\author{
Andrzej DROŻD $\dot{Z}^{1}$
}

\begin{abstract}
Drożdż A., 1979: Seasonal intake and digestibility of natural foods by roe-deer. Acta theriol., 24, 13: 137-170 [With 2 Tables \& 15 Figs.]

An estimate was made of seasonal consumption and digestibility in vivo of the natural food of the roe deer, and also of the digestibility of the dominating species of herb layer plants and browse cut every month in a deciduous tree stand of the Niepolomice Forest in the south of Poland by means of in vitro and nylon bag methods. Consumption of dry matter of browse depended on its digestibility and fibre content. The digestibility of browse, on the other hand, depended on the degree of phenological development of plants. A negative correlation was found between digestibility and fibre contents in food and a positive correlation for protein content. Digestibility in vitro is greater in the case of the leaves of trees and bushes than browse, while the digestibility of herb layer plants was greater throughout the whole growing season than that of browse. The results of examination of digestibility in vitro of mixed diets (herb layer plants and browse) did not show that herb layer plants have any important effect on the digestibility of browse. The high degree of correlation between digestibility in vivo and in vitro $(r=0.980)$, and a knowledge of the relation between food intake and digestibility, made it possible to draw up an equation evaluating the level of the roe-deer's dry matter intake $(D M D)$ with known digestibility in vitro (IVDMD) of food: $D M I=9.07+0.927$ IVDMD. Food with minimum 58\% digestibility is required to cover the energetic maintenance costs of the roe-deer. It was found that the food supply of deer in winter depends not on the amount of browse, but on its digestibility and the possibility of supplementing it by easily digestible food herb layer plants, grass or leaves.
\end{abstract}

[Jagiellonian Univ., Dept. Anim. Ecol., Karasia 6, 30-060 Kraków]

\section{INTRODUCTION}

Rational hunting management involves definition of what is knowr as the food carrying capacity of a given habitat (D z i ęciołow ski, 1970), and to define this it is essential to have data on the population's consumption level and food supply (G rodzinski, 1975). When amount of production and natural food supply, and also consumption, are known, it is possible to evaluate the direct effect of the population on the habitat and to arrive at decisions to maintain the optimum number of individuals in a given area.

1 Present address: [Inst. Zootechnics, Sheep Exp. Stat., Bielanka, 34-423 Sieniawa Poland]. 
The studies made up to the present on the food supply of deer, carried out from the aspect of amount of biomass, dry matter or energy of the food produced per unit of area (D z i ęciołowski, 1970; B obek et al., 1972; B obek et al., 1975) are insufficient. The natural food of deer is subject to considerable variations during the yearly cycle, both in respect of chemical composition and nutritive value, and therefore intensive studies aimed at defining its quality are essential. The nutritive value, and not the amount of food available, determines the level of consumption and its utilization by animals ( $\mathrm{N} \mathrm{a} \mathrm{g} \mathrm{y} \mathrm{et} \mathrm{al.,} \mathrm{1969;}$ Morris \& Kovner, 1970; A m mann et al., 1973). The quality of food also determines rate of growth (N e w s o m e et al., 1968; U $11 \mathrm{rey}$ et al., 1967; $\mathrm{N}$ ord a $\mathrm{n}$ et al., 1970), breeding success ( $\mathrm{N}$ ordan et al., 1968), the animal's condition, length of life, and ability to survive through unfavourable winter conditions (U rness et al., 1971).

Nutritive value should therefore, in addition to estimation of the natural food supply, be the basic criterion for evaluating the food carrying capacity of the habitat for deer. A measure of the nutritive value of food is, according to B a r nes (1965), its chemical composition and digestibility. These two parameters also exert a decisive influence on the animals' food preferences in relation to different plants (Van D y n e \& $\mathrm{H} \mathrm{eady}$, 1965) and also of parts of such plants (Cowan et al., 1970).

Determination of the digestibility of natural food over the yearly cycle permits of estimating the food supply for animals in the given area in categories of the sum total of total digestible nutrients (TDN), digestible energy $(D E)$, or dry matter digestibility $(D M D)$, while a knowledge of the relation between food digestibility and its voluntary intake (VI) permits of evaluating the possibility of supplying the energetic cost of the animals' maintenance, depending on the food currently available.

The classic time-consuming method, involving complete collection of faeces and a large amount of food, is inadequate for a complex evaluation of the digestibility of natural food consisting of a large number of plant species. An additional difficulty in using this method for wild animals is the necessity for elimination of selective consumption of the diet supplied. In such studies it is consequently essential to use microdigestion trials, either with nylon bags or the method in vitro simulating rumen fermentation under artificial conditions.

The great degree of similarity between the rumen physiology of deer and sheep (C ow a n et al., 1970; Short, 1970) permits not only of using the rumen fluid of fistulated sheep for studies on digestion in vitro, but also of using the method for evaluating digestibility in vivo 
in nylon bags containing food samples inserted for a certain period into the rumen of fistulated sheep. The fact that the samples are digested under the natural conditions in the animal's rumen (in vivo) makes this method of great advantage. The problem then arises as to what degree results obtained by means of the microdigestion methods agree with results obtained by the classic method.

The present study has been devoted to evaluation of the digestibility of dominating species of plants forming the natural food of roe-deer over the course of a year. Chief emphasis was laid on analysis of the value of the roe-deer's winter food, taking into consideration, in addition to browse, which has hitherto been considered their dominating food (S i u d a et al., 1969), the digestibility in vitro of herb layer plants, since studies so far made on the digestibility of browse consumed by roe-deer have shown that browse itself cannot form a sufficient food for these animals during winter (D rożd $\dot{z}$ \& Osiecki, 1973; D r o żd ż et al., 1975).

The wide range of studies carried out in Poland on the role of ungulates in forest ecosystems has included detailed evaluation of the food supply of deer (B obek et al., 1974; Grodzińs ki \& Pucek, 1975). The question then arises as to the value represented by this potential food of deer and to what degree it can be used by roe-deer.

The purpose of this study was: (1) to define the digestibility of natural food during the yearly cycle, taking into consideration the critical winter period, using both classic and micro-digestion methods, (2) to estimate food consumption by roe-deer depending on chemical composition, digestibility and the season, (3) to estimate the nutritive value of food available to roe-deer over the yearly cycle.

\section{MATERIAL AND METHODS}

\subsection{Examination of Digestibility by the Classic Method}

Studies on the digestibility in vivo of natural food were carried out on 10 roe-deer of both sexes, using the method described by Drożd \& Osiecki (1973). The roe-deer were fed in spring, summer and autumn on the current year's new-growth branches together with leaves, using 3-4 species in different combinations, and in winter twigs only of not more than $3 \mathrm{~mm}$ in diameter, since the shoots most often cropped by roe-deer under natural conditions are from 2 to $4 \mathrm{~mm}$ in diameter (B o b e $\mathrm{k}$ et al., 1978).

In order to compare results obtained by the classic method with results obtained by the use of micro-digestion methods, 30 experiments on digestion were chosen (Dró̇dż \& Osiecki, 1973; Drożd et al., 1975; Pietrzak, 1974) in which examination was made over the whole of a year of consumption and digestibility of diets consisting of the following species of trees and shrubs: Abies alba, Betula 
verrucosa, Carpinus betulus, Corylus avellana, Fagus silvatica, Populus tremula, Rubus idaeus, Quercus robur, Salix caprea, Tilia cordata, Vaccinium myrtillus.

Representative samples of food for chemical and micro-digestion analyses were prepared, bearing in mind the food preferences shown by roe-deer during the course of the experiment. Standard chemical analysis was used for both food and faeces (A.O.A.C., 1960), which were burnt in a bomb calorimeter.

\subsection{Examination of Digestibility by the in vitro Method}

In vitro dry mass digestibility (IVDMD) of browse and herb layer plants samples was defined after Tille y \& Terry (1963). Analysis was also made of representative food samples from the above-mentioned digestion experiments, the terminal parts of new growth twigs cut every month, and also of parts of herb layer plants collected in the Niepolomice Forest near Kraków in stands of Tilio-Carpinetum. In summer the terminal parts were cut together with leaves, but in winter the leafless ends of twigs only. Samples of twigs and herb layer plants were dried, ground, sifted through a sieve, again dried and stored in airtight vessels. Material was cut from 12 species of trees and shrubs: Alnus glutinosa, Betula verrucosa, Carpinus betulus, Frangula alnus; Fraxinus excelsior, Populus tremula, Quercus robur, Rubus sp. Rubus idaeus, Salix caprea, Tilia cordata, Sambucus nigra. In May, September and November samples were taken of 10 dominating species of herb layer plants in the Niepolomice Forest and also samples of herb layer plants from different age classes of the forest (Tables 1, 2; see sect. 3.6.2.).

About $500 \mathrm{mg}$ of the sample in three repeats, and with a control sample, were fermented in test tubes of $100 \mathrm{~cm}^{3}$ capacity in the presence of rumen fluid and a buffer. The rumen fluid was drawn off into a thermos in the presence of $\mathrm{CO}_{2}$ from a fistulated sheep fed with hay. Not more than 30 minutes elapsed from the time of drawing off the fluid to the start of incubation, which ensured the vitality of Protozoa and good quality of the fluid ( $\mathrm{Schwartz} \& \mathrm{Nagy}, 1972$ ). Incubation temperature was $39^{\circ} \mathrm{C}$. Fermentation was terminated after 48 hours by means of hydrochloric acid, $\mathrm{pH}$ was reduced to 1.2. and the sample treated with pepsin. After a subsequent 48-hour period the contents of the test tubes were filtered through No. 388 filter paper, dried and dry matter loss calculated. Similar procedure was used with representative samples of food from the feeding experiments carried out by the method in vivo.

In vitro organic matter digestibility (IVOMD) was defined by burning samples before digestion and undigested parts of samples in a crucible. Calculations were then made, taking into account the ash content in a sample and its apparent digestibility (see section 3.8.).

\subsection{Evaluation of Digestibility by the Nylon Bag Method}

From 5-10 nylon bags containing $2 \mathrm{~g}$ samples were introduced through a fistula for a period of 48 hours into the rumen of a sheep, fed throughout the experiment on hay. These samples were prepared identically with those used for in vitro digestion testing. After the bags were removed from the rumen they were rinsed under running water to free them of external impurities, then rinsed in dishes separatel: and dried to constant weight. Digestibility was calculated from the difference in weight of the sample before and after digestion. Three representative samples from each species examined were digested in the way described, introducing them into the rumen in different combinations with other samples. 
In order to compare this method with that of $\mathrm{Tille} y$ \& $\mathrm{Ter} \mathrm{r}$ (1963) and avoid errors due to "physical losses" such as took place when rinsing the bags, the water in which they were rinsed was filtered through No. 388 filter paper. The residue on the filter paper was added to the undigested part of the sample. In this way a criterion of identical size of particles considered as digested (in both methods such particles as pass through filter paper No. 388) was maintained.

In order to ascertain whether easily digestible herb layer plants tend to increase the digestibility of tree shoots, mixed diets consisting of the herb layer plants Oxalis acetosella and Aegopodium podagraria $(H)$ and 12 species of tree shoots ( $T$ ) from May and June were mixed with each other in different ratios: $1 T: 1 H$, $2 T: 1 H, 1 H: 2 H$, and digested by the in vitro method. The winter shoots had a mean in vitro digestibility of $32 \%$, the spring shoots $-65 \%$ and herb layer plants $85 \%$.

The results were interpreted by calculating the equation of straight line regression, correlations and significance of differences (test $t$ ) in accordance with the generally accepted statistical methods.

\section{RESULTS}

\subsection{Chemical Composition of the Foods Examined}

The chemical composition of samples digested in vitro collected over the yearly cycle (average for 12 species), and chemical composition of foods, examined by both the in vitro and in vivo methods, are compared in Fig. 1. Contents of water, crude protein, fibre, ether extract, mineral substances and $\mathrm{N}$-free extract were analyzed and caloric value defined.

Water content in material collected every month decreased during the growing season. Branches with fresh new growth cut in May contained on an average $76 \%$ water. As growth proceeded water content was about $65 \%$ during the summer months, from 50 to $62 \%$ in autumn and decreased even more abruptly in winter after the leaves had fallen. Leafless branches had from 35 to $42 \%$ of water only (Fig. 1).

Protein content was also characterized by a distinct decrease. During the growing season $22 \%$ of protein was found in new-growth twigs in May, in summer - June, July - from 16 to $18 \%$, and in autumn there was not more thant $10 \%$ of this component. During the winter months there was from $6-7 \%$ of crude protein in shoots. Mineral substances exhibited a decrease in content from $8 \%$ in May to $3.5 \%$ in December.

The reverse relation was observed in respect of crude fibre content. The percentage of fibre increases with the growth of shoots, and consequently only $13.9 \%$ of fibre was found in the May new-growth twigs, but a maximum of as much as $40 \%$ in the mature ligneous winter twigs. The ether extract content varied from 2.4 to $7.8 \%$ and did not 
exhibit any distinct seasonal changes. The percentage of $\mathrm{N}$-free extract content was calculated from the difference between protein, fibre and mineral substances contents and fluctuated within limits of up to $50 \%$

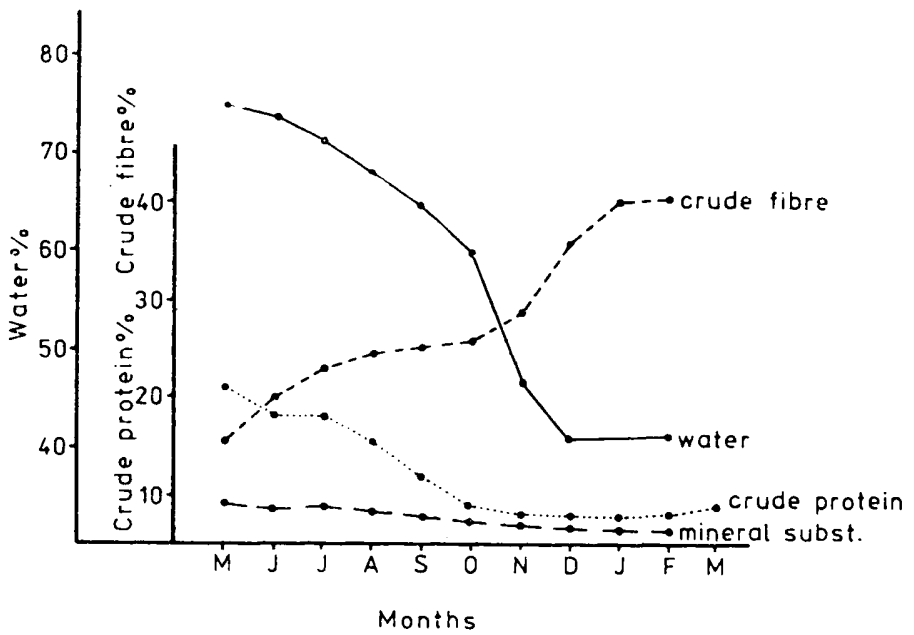

Fig. 1. Seasonal variations in the contents of certain chemical components in browse cut every month in a Tilio-Carpinetum stand of the Niepolomice Forest, expressed in percentages of dry matter.

of the dry mass of the samples examined. The caloric value of browse was on an average $4.8 \mathrm{kcal} / \mathrm{g}$ (from $4.4 \mathrm{kcal} / \mathrm{h}$ in spring to $4.9 \mathrm{kcal} / \mathrm{g}$ in winter).

\subsection{Food Consumption by Roe-deer over the Yearly Cycle}

\subsubsection{Consumption of Biomass, Dry Matter and Energy}

Natural food consumption by roe-deer varied within wide limits over the yearly cycle. Roe-deer feeding on leafless shoots consumed least in winter (December, January, February), from $580 \mathrm{~g}$ to $920 \mathrm{~g}$ of biomass, whereas in spring (May, June) animals fed on the young current newgrowth twigs consumed from 2350 to over $3000 \mathrm{~g}$ of biomass. Consumption expressed in dry matter, on account of the varying water content in shoots, took a different course and for the analogical periods was: in winter - average $450 \mathrm{~g}, 700 \mathrm{~g}$ in summer and $800 \mathrm{~g}$ in October. On account of the different weights of the animals examined consumption was expressed in kcal per metabolic body weight $\left(\mathrm{kg}^{0.75}\right)$.

Maximum food consumption was found in the spring months - 70$80 \mathrm{~g}$ of dry matter $/ \mathrm{kg}^{0.75}$, in summer about $60-70 \mathrm{~g}$, and in winter 
between 40 and $50 \mathrm{~g}$ dry matter $/ \mathrm{kg}^{0.75}$ per 24 hours. The curve of digestible energy consumption followed a very similar course over the yearly cycle. In spring roe-deer consumed on an average $250 \mathrm{kcal} / \mathrm{kg}^{0.75}$, in summer about $200 \mathrm{kcal}$ and in winter from November to April not more than $100 \mathrm{kcal}$ of digestible energy $/ \mathrm{kg}^{0.75}$ per 24 hours (Fig. 2).

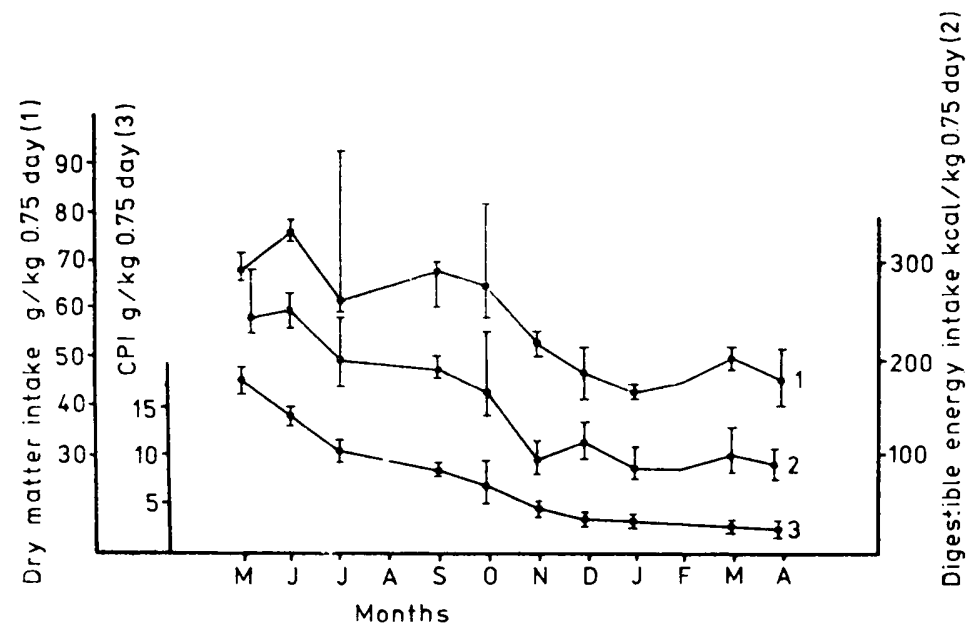

Fig. 2. Daily dry matter intake in $\mathrm{g} / \mathrm{kg}^{0.75}-1$, digestible energy in $\mathrm{kcal} / \mathrm{kg} 0.75-2$, and crude protein in $\mathrm{g} / \mathrm{kg}^{0.75}-3$ for roe-deer fed on browse at different times of the year. Curves drawn from mean values of 2-4 experiments. Full range of variation marked.

\subsection{Relation between Consumption and Digestibility and}

\section{Chemical Composition of Natural Food}

The level of consumption in roe-deer is clearly dependent on the digestibility of its food. Foods with dry matter digestibility of $30-40 \%$ were consumed in minimum amounts - about $35 \mathrm{~g}$ of dry matter $/ \mathrm{kg}^{0.75}$ per 24 hours. For every $1 \%$ of reduction in coefficient of dry matter digestibility $(D M D)$ roe-deer decreased dry matter intake (DMI) by about $1 \mathrm{~g}$ of dry matter of food $/ \mathrm{kg}^{0.75}$ (Fig. 3).

A similar relation was found between the coefficient of digestible energy $(D E)$ and daily digestible energy intake (DEI) (Fig. 4) and gross energy intake (Fig. 5) expressed in $\mathrm{kcal} / \mathrm{kg}^{0.75}$ per 24 hours, and between digestible energy intake $(D E I)$ and coefficient of dry matter digestibility $(D M D)$ of the given food (Fig. 6).

The value of digestible energy intake is also determined by the amount of energy obtained by roe-deer per $1 \mathrm{~g}$ of dry matter intake. While roe-deer obtain from 2.5 to $3.5 \mathrm{kcal}$ of digestible energy in 


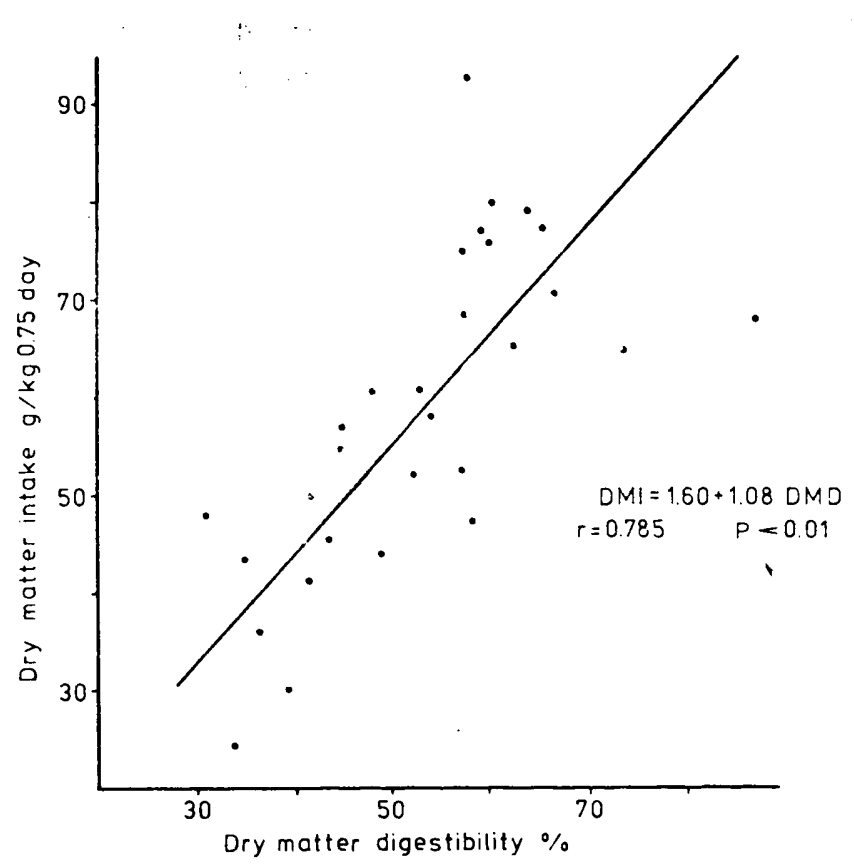

Fig. 3. Dry matter intake in $\mathrm{g} / \mathrm{kg}^{0.75}$ for roe-deer fed on natural food, depending on food digestibility. $D M I$ - dry matter intake, $D M D$ - dry matter digestibility.

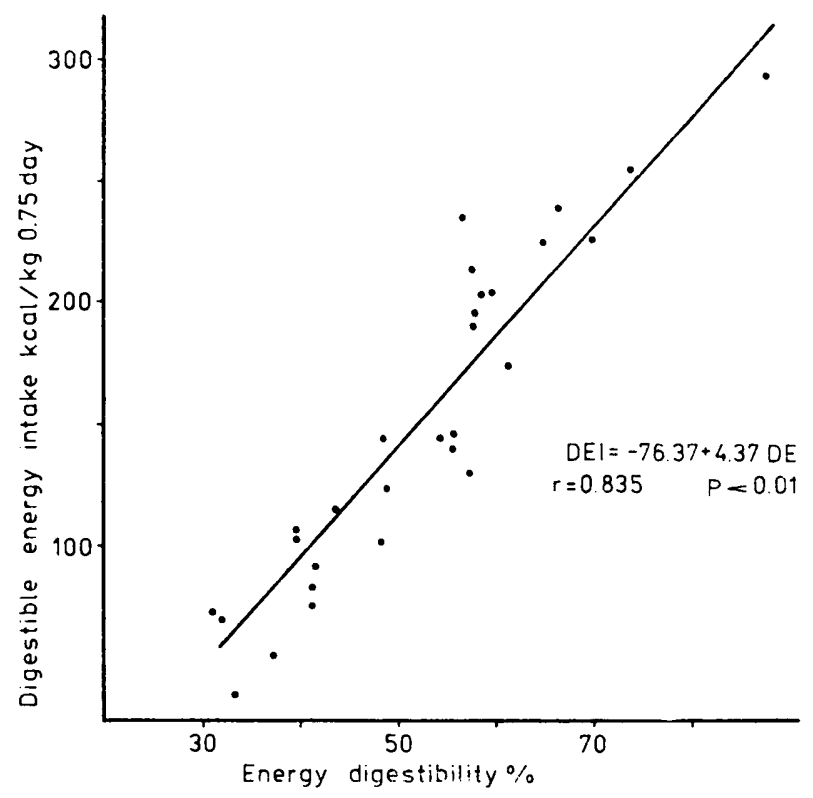

Fig. 4. Relation between energy digestibility $(E D)$ expressed in percentages and daily digestible energy intake $(D E I)$ for roe-deer in $\mathrm{kcal} / \mathrm{kg}^{0.75}$. 


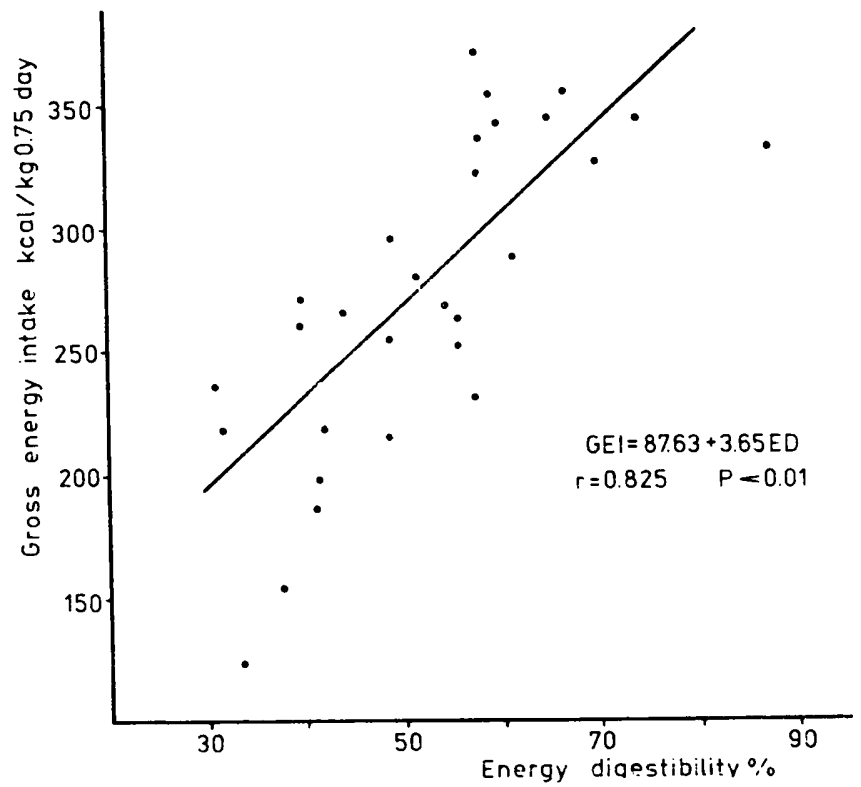

Fig. 5. Gross daily energy intake (GEI) expressed in $\mathrm{kcal} / \mathrm{kg}^{0.75}$ for roe-deer, depending on energy digestibility $(E D)$.

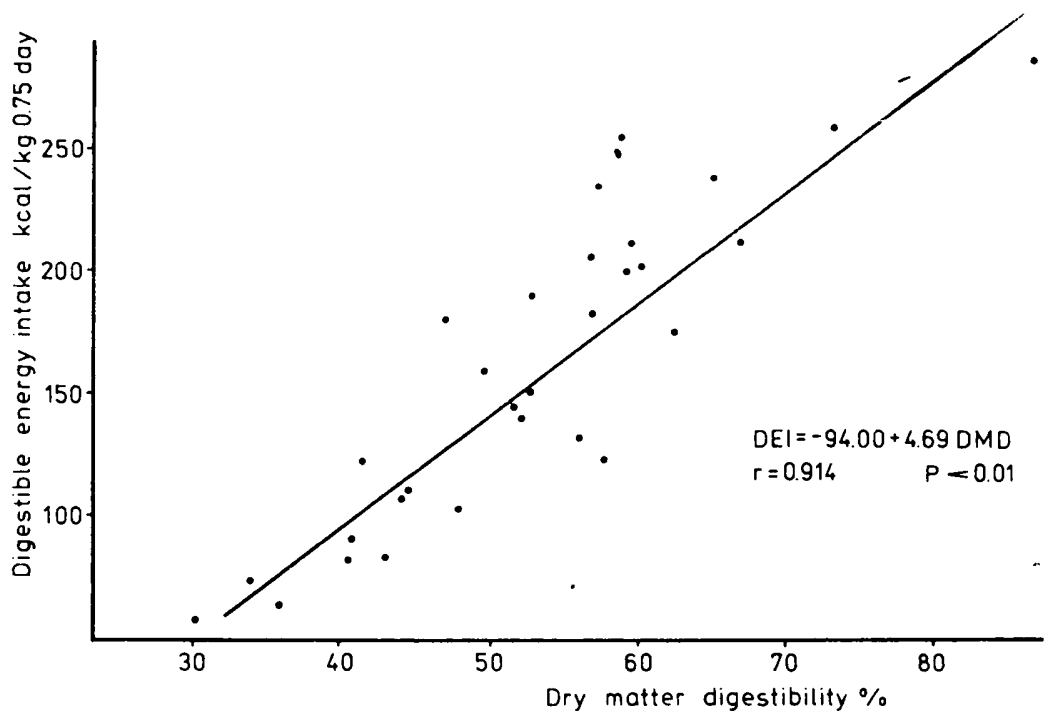

Fig. 6. Daily digestible energy intake $(D E I)$ for roe-deer expressed in $\mathrm{kcal} / \mathrm{kg} \mathbf{0 . 7 5}$, depending on dry matter digestibility of food (DMD). 
spring and summer from each gramme of dry matter intake, in winter this value does not exceed $2 \mathrm{kcal} / \mathrm{g}$.

It can be seen from the equation of regression (Fig. 7) that increase from 2 to $3 \mathrm{kcal}$ in digestible energy concentration $(D E C)$ obtained from $1 \mathrm{~g}$ of dry matter increases its consumption (DEI) by $100 \mathrm{kcal} / \mathrm{kg}^{0.75}$ per 24 hours. When roe-deer are fed on food supplying digestible energy

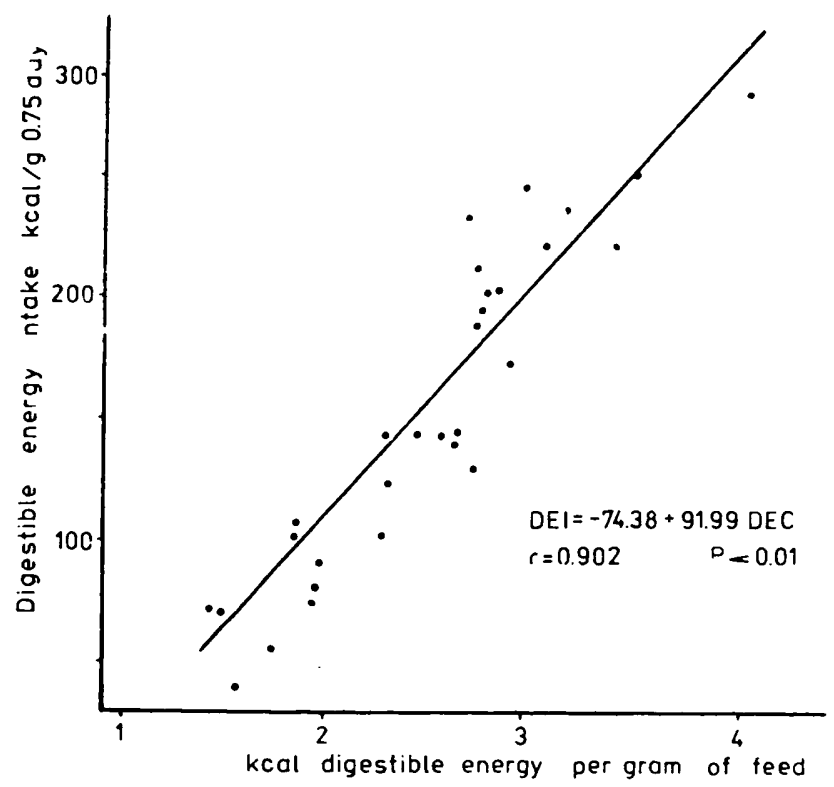

Fig. 7. Relation between daily energy intake $(D E I)$ for roe-deer, expressed in $\mathrm{kcal} / \mathrm{kg}$.75 and amount of digestible energy obtained by roe-deer from $1 \mathrm{~g}$ of digestible energy concentration (DEC).

of over $2 \mathrm{kcal} / \mathrm{g}$ there an increase in consumption is observed (Fig. 8). Below this value, mainly in winter, there is a decided decrease in consumption.

The level of consumption over a year is also determined by the chemical composition of the food available. The most important factor here is the devel of fibre and protein in the food. Winter foods with high fibre content are consumed in amounts far smaller than the actual energy needs of the animals. Browse containing from 30 to $40 \%$ of fibre is consumed in amounts of about $30 \mathrm{~g}$ dry matter $/ \mathrm{kg}^{0.75}$ per 24 hours (Fig. 9), whereas in spring, when there is only $10 \%$ of fibre in food $(F)$ this value is over $80 \mathrm{~g}$ dry mass $\mathrm{kg}^{0.75}$.

Similarly the crude protein content affects the roe-deer's food preferences in relation to food containing more of this component. When 
the level of food consumption was analyzed in relation to crude protein content it was found that the increasing percentage of protein in food is accompanied by an increase in consumption.

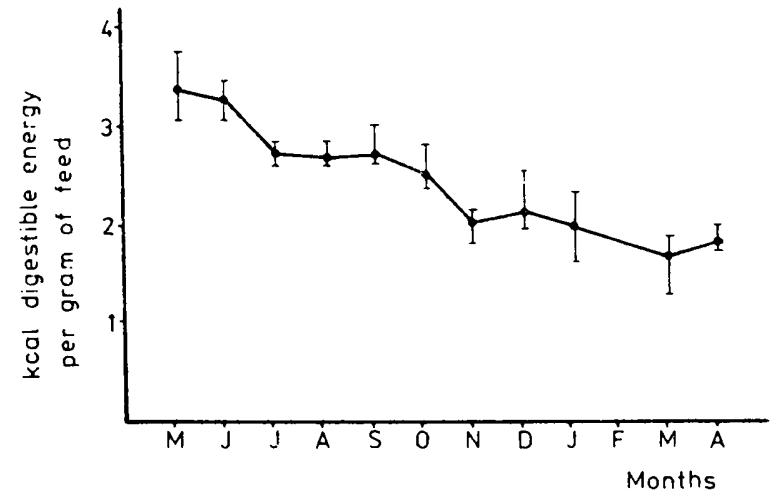

Fig. 8. Seasonal variations in amount of digestible energy obtained from $1 \mathrm{~g}$ of browse dry matter consumed by roe-deer.

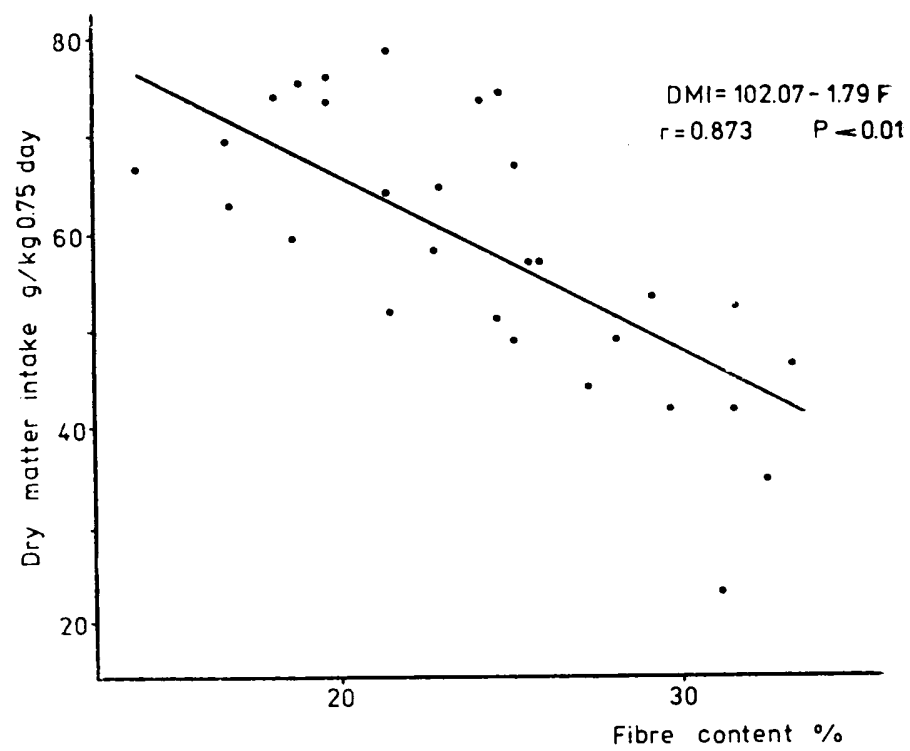

Fig. 9. Daily consumption of browse dry matter for roe-deer expressed in $\mathrm{g} / \mathrm{kg}^{0.75}$. depending on fibre contents in food. $D M I-$ dry matter intake, $F$ - fibre content. in food.

Crude protein consumption by roe-deer also varied seasonally (Fig. 2). In spring and summer the food on which the animals were fed containet $15-20 \%$ of protein, and consequently daily consumption varied from 10 to $17 \mathrm{~g} / \mathrm{kg}^{0.75}$ over the growing season depending on food. In win-. 
ter, as a result of reduced food consumption and the low content of this component in the food, consumption did not exceed $5 \mathrm{~g} / \mathrm{kg}^{0.75} / \mathrm{day}$.

\subsection{Digestibility of Natural Foods over the Yearly Cycle 3.4.1. Dry Matter Digestibility}

Dry matter digestibility varied considerably over the yearly cycle (Fig. 10). The highest digestibility coefficient was found when the roedeer were fed on May new-growth twigs of trees and shrubs. Dry matter digestibility of such foods was on an average $73.5 \%$, and $69 \%$ in June. From July to October the digestibility of browse declined slightly from 58 to $55 \%$. Between October and November, after the leaves had fallen, there was an abrupt decrease in the digestibility of such foods. In winter the digestibility coefficient of natural food consisting of the twigs of trees and shrubs was maintained on a constant level only slightly exceeding $40 \%$ (Fig. 10).

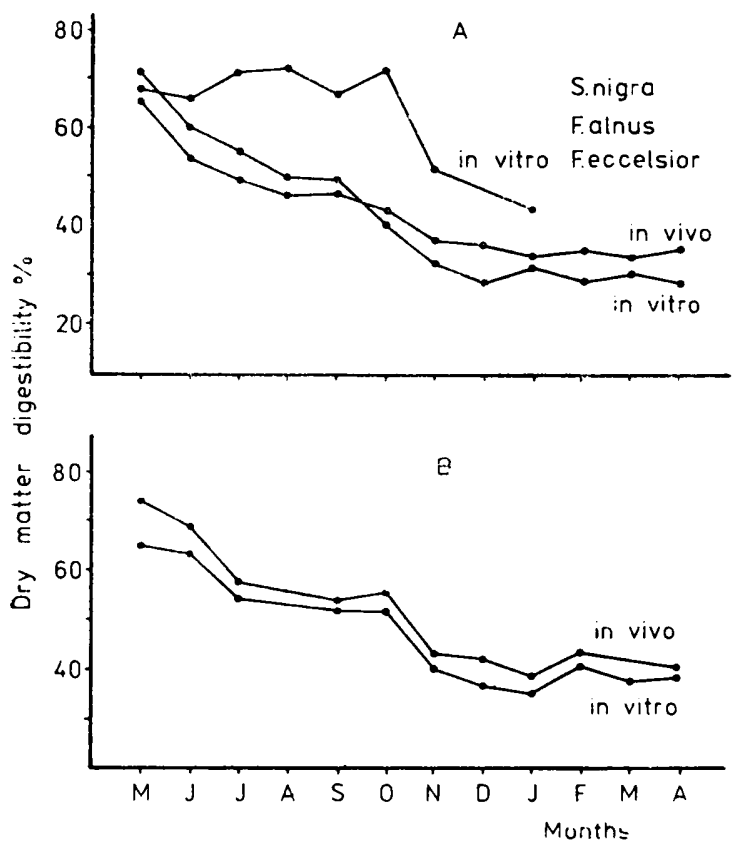

Fig. 10. (A) Average digestibility of browse dry matter over the yearly cycle, examined by: nylon bag method, for 9 species of trees and shrubs, in vitro for the same species, in vitro for 3 species (Sambucus nigra, Frangula alnus, Fraxinus excelsior). (B) Average digestibility of the dry matter of whole diets composed of twigs of trees and shrubs examined by in vitro method and in vivo method. 


\subsubsection{Organic Matter Digestibility}

The level of organic matter digestibility $(O M D)$ is the function of food digestibility and depends on the degree to which the animals make use of mineral substances. In feeding experiments it was found that the organic matter digestibility of browse was always a few per cent higher than dry matter digestibility and, within the range of digestibility coefficient from 40 to $80 \%$, is, according to the following equation:

$$
\begin{gathered}
O M D=4.54+0.974 D M D \quad r=0.994 \quad P<0.001 \\
\text { 3.5. Relation between Digestibility Coefficient and } \\
\text { Chemical Composition of Food }
\end{gathered}
$$

\subsection{Relation between Digestibility Coefficient and Chemical Composition of Food}

Fibre and crude protein contents were found to exert a marked effect on the digestibility of dry matter. The correlation of dry matter digestibility with fibre content in food $(F)$ is negative and highly statistically significant (Fig. 11).

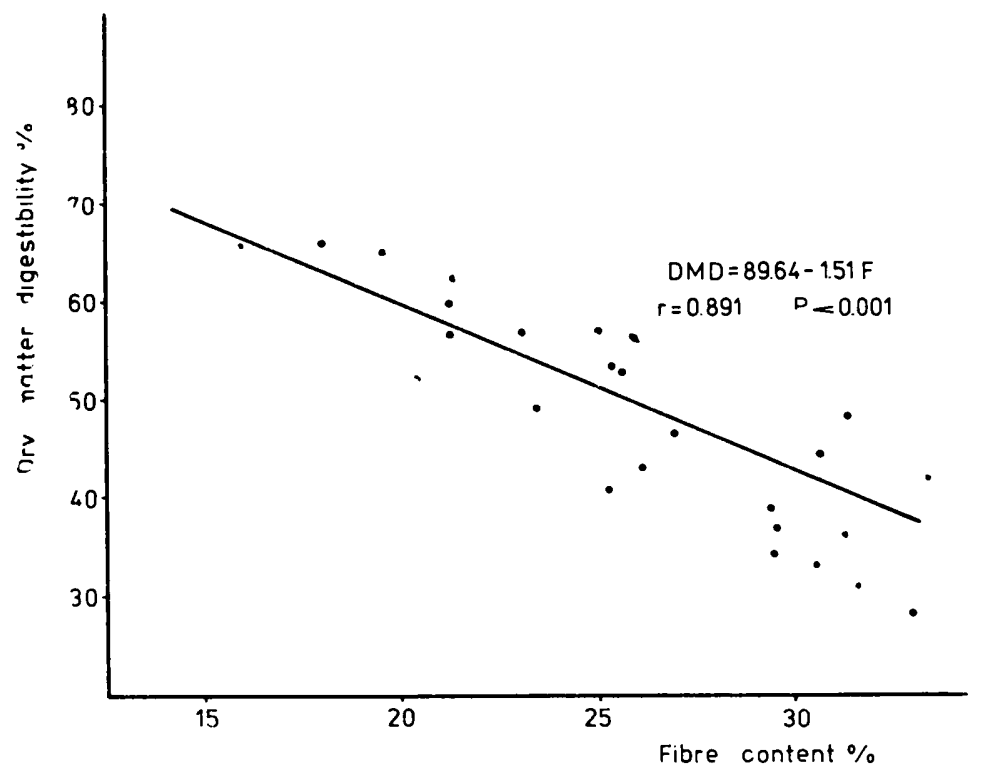

Fig. 11. Relation between dry matter digestibility of the roe-deer's food and crude fibre content in food. $D M D$ - dry matter digestibility $F$ - fibre content.

Since lower fibre content in browse is usually accompanied by a higher protein content, it is consequently possible to correlate protein content $(P C)$ with dry matter digestibility $(D M D)$.

$$
D M D=23.69+2.31 P C \quad r=0.899 \quad P<0.01
$$




\subsection{In vitro Digestibility of Natural Food}

\subsubsection{In vitro Digestibility of Browse}

The digestibility of browse samples taken at monthly intervals decreased over the growing season. Maximum in vitro dry matter digestibility was found in May - on an average $64.4 \%$ for the 9 species of trees and shrubs examined (Fig. 10). The most digestible during this period proved to be elder $-78.4 \%$, oak $78.0 \%$ and lime $75 \%$, while alder was the least digestible $-54.6 \%$. After 25 days of growth from the time of taking the first samples in June the average coefficient of digestibility in vitro (IVDMD) was almost $11 \%$ lower. A slightly smaller decrease of only about $5 \%$ was found in July. Throughout the whole of the summer up to the time the leaves fell the digestibility of browse decreased by a further $5 \%$, with a value of $43.1 \%$ in October. In summer over $50 \%$ digestibility was found for the species of trees examined, as follows: lime 55\%, willow $55 \%$ and hornbeam $51 \%$. After the leaves fall, in vitro dry matter digestibility of browse decreases and never exceeds $35 \%$ throughout the whole winter. The lowest degree of digestibility is found during this period for oak $-24.7 \%$, birch $-27.7 \%$ o and alder $-26.6 \%$.

In respect of this characteristic ash, buckthorn and elder have slightly different values (Fig. 10). The new growth of the above species is highly digestible throughout the whole growing season, in both summer and autumn, and buckthorn and elder are easily digestible, even after the leaves fall. Their digestibility is respectively 46.6 and $38.6 \%$, but the leafless twigs of the ash are exceptionally indigestible $-22 \%$. The greatest differentiation in respect of browse digestibility was found in autumn $(22-46 \%)$, due to the different character of digestibility of certain components of the food available to roe-deer in the Niepolomice Forest, namely buckthorn, elder and ash.

\subsubsection{In vitro Digestibility of the Leaves of Trees and Shrubs}

In vitro digestibility of the leaves of trees during the growing season was similar to that of whole twigs, although the rate of the decrease in digestibility was slower. In May digestibility was an average $70^{\circ} \%$ $(80 \%$ - oak, $78 \%$ - lime, $65 \%$ - alder) (Fig. 12). The rate of decline in digestibility of the leaves of trees and shrubs over the growing season is not uniform. Digestibility decreases more quickly in the leaves of oak, birch and alder than in lime, willow or ash. An example of the diminishing digestibility of the leaves of oak and elder is given in Fig. 13. While the digestibility of oak leaves - an important component of food of roe-deer in the deciduous treestand of the Niepolomice Forest - 
declines rapidly, in the case of elder leaves this is maintained on a very high level throughout the greater part of the season.

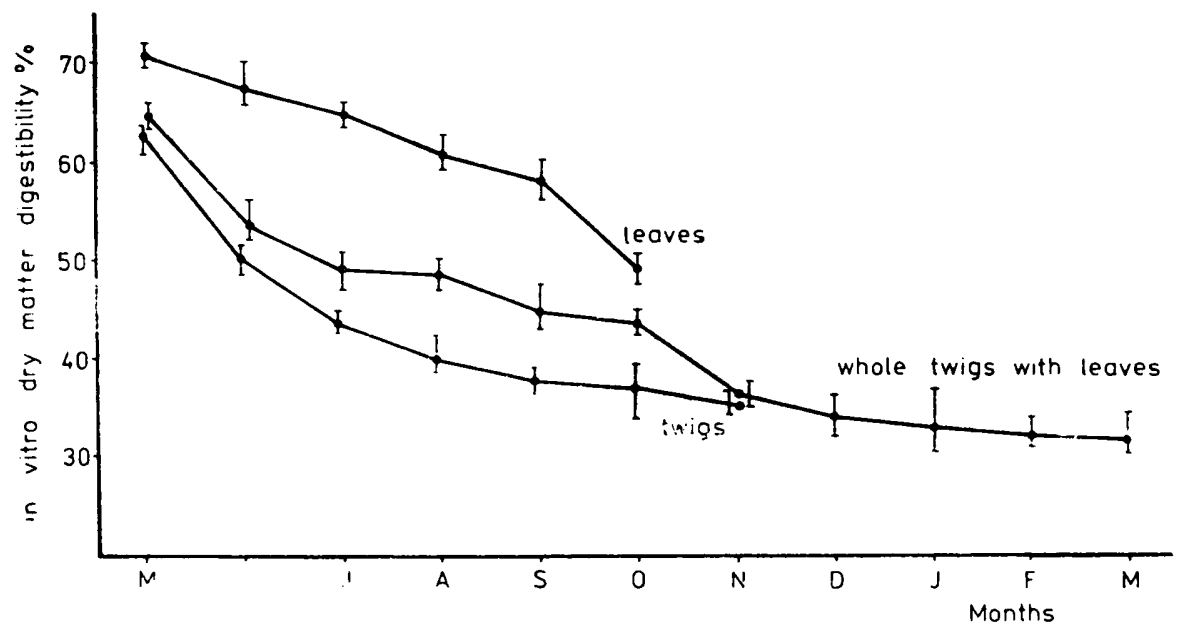

Fig. 12. Comparison of in vitro digestibility of leaves, browse and tree and bush twigs alone. Complete range of variability given.

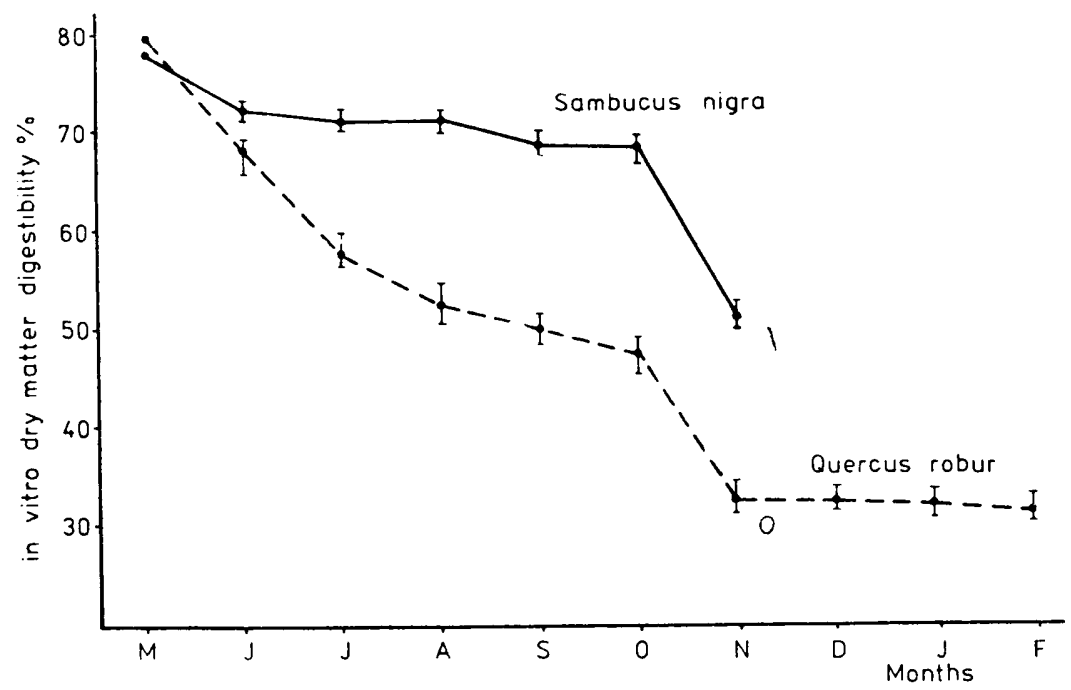

Fig. 13. In vitro digestibility of twig samples of Quercus robur and Sambucus nigra.

The digestibility of the current year's new-growth twigs is very similar to that of leaves during the initial period of the growing season, but as the season advances it decreases more abruptly than that of leaves, reaching an average digestibility of $32-35 \%$ during the winter. 
Maximum digestibility during winter found for twigs of trees was characteristic of the willow $-40 \%$.

The ends of twigs, together with winter buds, having a higher protein content than the whole twigs, are also characterized by a higher degree of digestibility in relation to the whole annual new-growth twigs taken for analysis. For the 4 species of trees examined these values were the lowest in alder and birch ( 36 and $43 \%$ ) and highest in willow and lime (48 and $51 \%$ ). On account of the high protein content in these parts of twigs and their greater digestibility selection of these parts of plants by roe-deer decidedly improves the animals' energy balance.

\subsubsection{In vitro Digestibility of Herb Layer Plants}

In vitro digestibility of species of herb layer plants of the deciduous treestands of the Niepolomice Forest in given months of the growing season (May, July, September, November) are set out in Table 1.

Table 1

In vitro digestibility of herb layer plants of a deciduous tree stand in the Niepolomice Forest in certain periods of the growing season (expressed in percentages of dry matter).

\begin{tabular}{lcccc}
\hline \multicolumn{1}{c}{ Species } & May & July & September & November \\
\hline Aegopodium podagraria & 72.0 & 69.2 & 54.0 & 48.0 \\
Anemone nemorosa & 80.5 & 62.0 & - & - \\
Asarum europaeum & 60.1 & 62.3 & 58.4 & 55.2 \\
Carex brizoides & 76.2 & 68.1 & 55.1 & 48.1 \\
Ficaria verna & 84.8 & 83.7 & 85.2 & - \\
Impatiens noli tangere & 75.2 & 72.1 & 73.1 & - \\
Mycelis muralis & 85.0 & 83.1 & 72.1 & - \\
Oxalis acetosella & 85.3 & 84.3 & 85.2 & 48.3 \\
Rubus sp. (leaves) & 69.2 & 58.2 & 51.5 & - \\
Viola silvestris & 81.2 & 82.1 & - & 48.3 \\
Grasses (Graminae) & 76.2 & 68.1 & 55.1 & 38.8 \\
Sedge (Carex sp.) & 75.1 & 65.8 & 52.2 & - \\
Dry leaves of trees & - & - & - & \\
\hline
\end{tabular}

Plants were characterized by maximum digestibility at the beginning of the growing season - in May, Oxalis acetosella over $85 \%$, Mycelis muralis $85 \%$, but only $60 \%$ for Asarum europaeum. As the growing season advanced, digestibility in general decreased, except that digestibility in Oxalis acetosella, Mycelis muralis and Ficaria verna was maintained on a high level throughout the whole season (over $70 \%$ ). Minimum digestibility was found for sedge and grasses, particulary in autumn ( 42 to $45 \%$ ).

The digestibility of herb layer plants is different in different age classes of the forest, as shown in Table 2. While in vitro digestibility 
is similar and higher in both the plantations and the old tree stand in May (average $75 \%$ ), in the summer and autumn months there were considerable differences found in the different age classes of the treestand. In vitro digestibility decreased most rapidly in plantations, where the herb layer consisted mainly of grasses, and most slowly in the old tree stand, a considerable percentage of the herb layer of which con-

Table 2

In vitro digestibility of herb layer plants in different age classes of a deciduous tree stand in the Niepolomice Forest (in percentages of dry matter).

\begin{tabular}{lcccc}
\hline Age classes of tree stand & May & July & September & November \\
\hline Seedling plantations & 75.2 & 65.0 & 48.0 & 33.2 \\
Young tree plantations & 74.2 & 68.0 & 51.0 & 39.4 \\
Fully-grown trees & 71.2 & 68.5 & 51.4 & 42.0 \\
Old trees stand & 75.8 & 72.0 & 70.8 & 45.1 \\
Average & 74.1 & 68.4 & 55.3 & 39.9 \\
\hline
\end{tabular}

sists of dicotyledonous plants. These plants are usually characterized by a greater digestibility in vitro than monocotyledonous plants (D i e t z, 1970).

\subsection{Examination of Browse Digestibility by the Nylon Bag Method}

The results of digestibility tests of the twigs of 12 species of trees and shrubs evaluated by the nylon bag method are given in Fig. 10. Maximum digestibility was found, as was the case with the in vitro method, for material cut in May. The digestibility curve falls in a similar course, although when the two methods are compared it was found that from May to September in vivo digestibility in nylon bags was always higher than in vitro digestibility found by the method of $\mathrm{T}$ ill e y \& Terry (1963) by an average of 5\% (0.8 SD). The reverse process took place in autumn and winter, when digestibility of samples in nylon bags was on an average $4.5 \%$ ( $\pm 0.7 \mathrm{SD})$.

Correlation between the in vitro method (IVDMD) and nylon bag method $(N B D M D)$ is highly significant and was $r=0.973$ and is described by the following equation:

$$
I V D M D=12.65+0.699 \text { NBDMD } \quad P<0.01
$$

The results given in Fig. 10 represent data corrected by the method described in section 2.3. Of the samples examined, $4.1 \%$ passed through to the water during rinsing, raising the apparent digestibility of the sample tested by this value. With digestion of easily-digestible food (leaves, herb layer plants) this percentage was higher, being on an average $6 \%$, but $1-3 \%$ lower for digestion of winter twigs. When com- 
paring the two methods the same criteria were used for estimating loss of the substrate examined, defined as a percentage of digestibility of the given food, by converting particles of food considered digestible to identical size (section 2.3.).

\subsection{In vitro Organic Matter Digestibility}

In vitro organic matter digestibility was calculated by means of the equation

$$
I V O M D=\frac{100 D M A-(A \times A D)}{(100-A)}
$$

where $A-\%$ of ash in the sample

$A D$ - apparent digestibility of ash in $\%$

Organic matter digestibility (IVOMD) was lower than the in vitro dry matter digestibility (IVDMD) and for the 12 species of browse examined was as shown in the following equation:

$$
\text { IVOMD }=-3.8+1.01 \text { IVDMD } \quad r=0.907 \quad P<0.01
$$

The fact accounting for the different level of organic matter digestibility in the two methods, in vitro and in vivo, is the difference in ash digestibility. Mineral matter digestibility was on an average lower with the in vivo method than dry matter digestibility. The reverse was the case with mineral matter digestibility with the in vitro method.

\subsection{In vitro Digestibility of Mixed Diets}

The in vitro method makes it possible to arrive at quick evaluation of digestibility, not only of the various components of diets but also of mixtures of foods. The question then arises as to whether more easily digested components affect the less digestible ones and whether the factual digestibility of the mixture in the experiment in vitro is the same as digestibility calculated by means of the weighed mean, taking into consideration the percentages of different components in the mixture. Fig. 14 shows a comparison of predicted - calculated digestibility and the experimentally obtained actual digestibility. Herb layer plants contribute very little to increasing in vitro digestibility of the whole diet. In both summer, when digestibility of shoots and twigs did not greatly differ from the digestibility of herb layer plants, or in winter when there was considerable difference between the digestibility of mixed components, herb layer plants were not found to exert a statistically significant influence on browse digestibility. Increase of digestibility in both experiments varied from $2-4$ digestibility units (Fig. 14). 


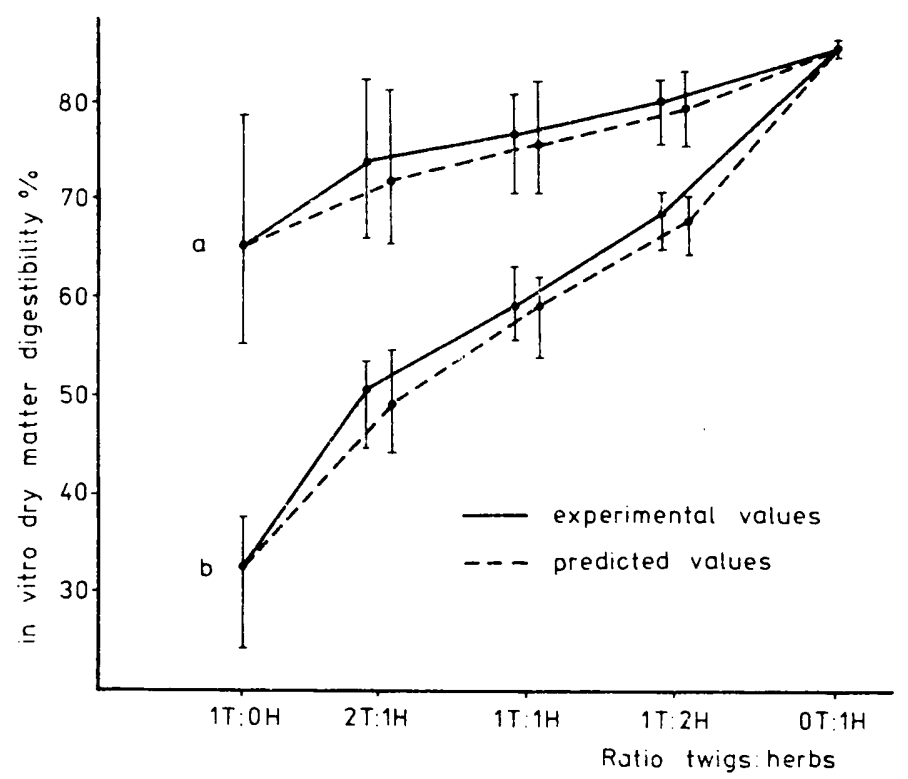

Fig. 14. In vitro digestibility of samples consisting of shoots of trees and herb layer plants, mixed in varying ratios.

a - shoots in May, b - shoots in January. Complete range of variations in experimentally obtained results indicated by dotted line, results anticipated from calculation-continuous line. Each point represents average for 12 species of shoots examined.

\subsection{Relation between Digestibility in vitro and in vivo}

Representative samples of the diets, the digestibility of which had been tested by the classic in vivo method, were tested for in vitro digestibility (Fig. 10). A high degree of correlation was found between the two methods, of $r=0.980$, and the relation between in vivo dry matter digestibility $(D M D)$ and in vitro dry matter digestibility (IVDMD) was expressed by the following equation:

$$
D M D=2.16+1.03 \text { IVDMD } \quad r=0.980 \quad P<0.001
$$

A similarly high correlation was found between mean in vitro digestibility of 9 species of trees and shrubs (IVDMD), the twigs of which had been analyzed for digestibility at different times of the year, and in vivo digestibility of different mixtures of diets composed of browse (Fig. 10).

$$
\text { in vivo } D M D=6.0+1.09 \text { IVDMD } \quad r=0.968 \quad P<0.01
$$

This points to the fact that the digestibility of almost optionally composed diets, consisting of the browse of different species of trees, is determined by the phenological state of the latter. 


\subsection{Evaluation of Food Consumption by Roe-deer on the Basis of its in vitro Digestibility}

Establishment of the relation between digestibility in vitro and in vivo permits of foreseeing the roe-deer's consumption of natural food of known in vitro digestibility. The experiments made on digestibility show that the relation between dry matter intake $(D M I)$ by roe-deer expressed in grammes $/ \mathrm{kg}^{0.75}$ per 24 hours, and their in vitro digestibility $(I V D M D)$ is

$$
D M I=9.07+0.927 \text { IVDMD } \quad r=0.689 \quad P<0.01
$$

while the relation between digestible energy intake $(D E I)$, expressed in $\mathrm{kcal} / \mathrm{kg}^{0.75} / 24$ hours, and in vitro digestibility (IVDMD) was estimated as follows:

$$
D E I=-99.0+4.69 \text { IVDMD } \quad r=0.826 \quad P<0.01
$$

\section{DISCUSSION}

\subsection{Application of Microdigestion Methods to Evaluation of Digestibility}

In view of the low costs and rapidity of analysis, microdigestion methods are widely used in studies on animal foods (P i otrow ski, 1974). The natural food of deer, consisting of over fifty species of plants consumed at different stages of their phenological development, forms ideal material for such studies. The use of microdigestion techniques makes it possible at least partly to eliminate studies on wild animals which frequently, when confined, behave differently than under natural free conditions ( $\mathrm{M} \mathrm{a} \mathrm{u} \mathrm{tz}, 1971$ ). Food preferences add considerably to the difficulty of experiments on digestibility carried out by classic or indicator methods, and may lead to erroneous conclusions. These methods also make it possible to trace the digestibility of different species of plants or parts of such plants. It was found (Fig. 10,13) that in vitro digestibility of three species: Sambucus nigra, Fraxinus excelsior and Frangula alnus, is maintained on a high level throughout the whole growing season, while Sambucus nigra and Frangula alnus are also easily digested in winter. These species are distinctly preferred by roe-deer ( $\mathrm{B}$ o b e k et al., 1978) and undoubtedly form an important component of their diet.

The results of this study revealed a high degree of agreement between the in vivo and in vitro methods in respect of digestion of whole mixtures of food, and are also very similar to the results obtained by other authors (M e yer et al., 1971; J oshi, 1972; S a unders et al., 1973; $\mathrm{Sh}$ or t et al., 1973). As a result it is possible to foresee, with a considerable degree of probability, the level of voluntary intake by roe- 
deer, of dry matter, or of energy, on the basis of a knowledge of in vitro digestibility of natural food (equations 14,15 ).

Digestibility tested by the nylon bag method $(N B T)$ determined the loss of dry food matter contained in nylon bags and inserted into the rumen. This result depends to a considerable degree on the length of time for which the sample remains in the rumen ( $N$ e a the ry, 1969) and the size of the particles in the sample (Van $\mathrm{K} \mathrm{e} \mathrm{ure} \mathrm{n} \& \mathrm{H}$ e in e$m$ a $n$, 1962). Many authors have found a high degree of correlation between digestibility obtained by the NBT method and by conventional methods (Lusk, 1962; Low rey et al., 1968). The studies made by $\mathrm{N}$ e a th e r y (1972) show that results of dry matter and fibre digestibility are closest to the results obtained by classic methods, and least similar those of ether extract and protein. This is easy to understand, since proteins are digested in the lower parts of the alimentary tract ( Church, 1974). Simulation of this process is the second stage of digestion by pepsin in the in vitro method. For this reason, inter alia, results obtained by the nylon bag method are usually lower than those obtained by the two-stage in vitro method ( $\mathrm{N}$ e a thery, 1972). Samples of browse in autumn and winter (Fig. 10) did in fact reveal lesser digestibility in nylon bags than did the in vitro method, but this value was higher in spring samples. This phenomenon may be accounted for by the diametrically different character of summer samples (chiefly leaves) and winter samples (ligneous twigs). While the first may be very finely ground, the second usually have larger particles. Thus despite the introduction of corrections for "physical losses « (cf. 3.7.), making it possible to compare with results obtained in vitro, the samples showed a loss of dry matter several percent higher.

Very similar results were obtained by Monson et al. (1969) in studies, using both methods, on digestibility of grass leaves and stems in different stages of their phenological development. These authors confirmed the high degree of correlation between the two methods $(r=0.81$ for all samples tested) and showed that in vitro digestibility usually exceeds NBT digestibility, although the young new-growth of grasses possessed higher NBT digestibility than obtained by the in vitro method. NBT digestibility of the later phenological stages of grass stems, like that of the ligneous twigs in this study, was far lower than was the case using the in vitro method. Differences in the digestibility of these samples was as much as 10 digestibility units.

It is clear from the above discussion that by using Tilley and Terry's method results can be obtained which vary far less than when the nylon bag method is used. This method can be used to replace to a great extent 
the expensive and time-consuming conventional method in studies on the natural food of deer.

1

\subsection{Relation between Digestibility and Degree of Phenological Development}

The three methods used showed clearly and unequivocally that digestibility of natural food varies with growth of plants. The process of browse maturation is always accompanied by a decrease in water and protein content and increase in fibre contents (Fig. 1; Short et al., 1966; Short \& $\mathrm{Harrel}$, 1969; B obek et al., 1974). In spring, for instance, young new-growth twigs contain almost $20 \%$ of crude protein and not even $20 \%$ of fibre, whereas in winter they contain less than $5 \%$ protein and fibre content increases to $40 \%$ (Fig. 1). The phenological state of the food available undoubtedly affects the given food preferences of deer observed by Borowski \& Kossak (1975) in different seasons. As in the case of grasses of papilionaceous plants, the time of harvesting, or the given system of grazing and fertilizing may cause far-reaching changes in the nutrient value and digestibility of fodder. The chief factor reducing food digestibility is usually fibre. In the present study a very distinct correlation was found between increase in fibre content in browse and dry matter digestibility (Fig. 11). A large

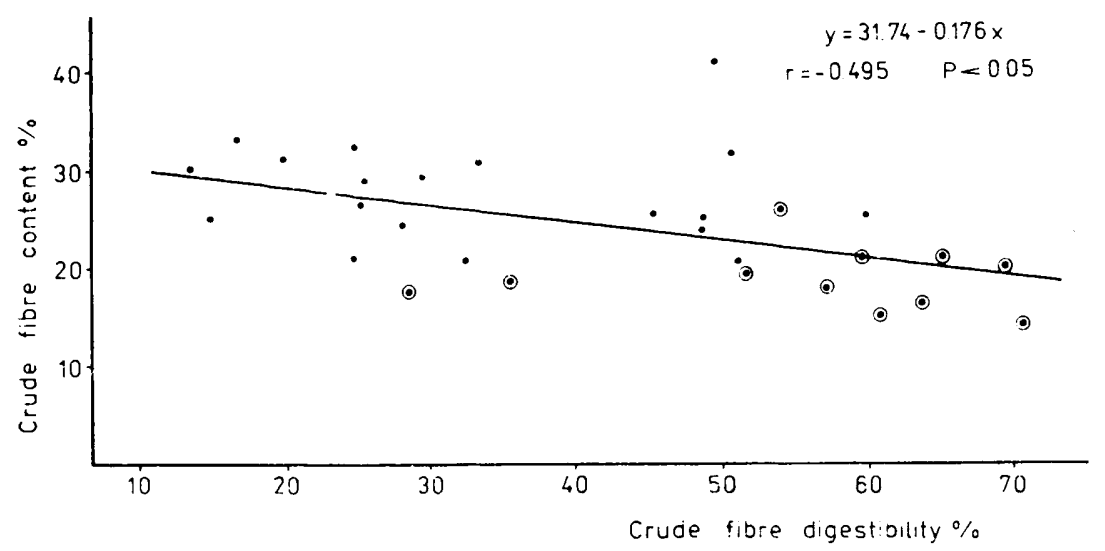

Fig. 15. Relation between coefficient of fibre digestibility and fibre content in food. Points within circles represent data on foods from spring and early summer period.

number of authors have found similar relations for many species of grasses in different stages of phenological development (cf. e.g., Z i ołe c k a, 1969).

A comparison of the relations between fibre digestibility $(x)$ and its 
content in browse $(y)$ is given in Fig. 15. The more fibre there was in the food, the lower its digestibility. The fact that fibre was digested by roe-deer to a different degree, depending on the phenological state of the shoots fed to the animals, is evidence of its greatly varied chemical composition. The fibre in spring twigs was digested better than in winter browse (Fig. 15). Similar results were obtained by $\mathrm{W}$ a 11 a ce \& Van Dyne (1970) for crude fibre, which was better utilized by cattle in June than in August, and by $\mathrm{S} h$ or t \& R e a go r (1970) for cell wall constituent $(C W C)$, proving that the smaller amount of $C W C$ in the food of white-tailed deer, the better the digestibility of this fraction. This is connected inter alia with seasonal variations in the quality of lignine which, as one of the chief components of fibre, determines the digestibility of food to a considerable degree. Evidence of chemical variations in lignine have been giver by Millet et al. (1970) and B a ker (1973), who found a higher degree of in vitro digestibility for the lignine of deciduous tree species (birch, oak) than coniferous (spruce, pine). Similarly Pe r za n ow ski (1978) found that the lignine of herb layer plants is more digestible than that contained in winter twigs.

Protein content, deficiency of which reduces the total digestibility of food, also affects food digestibility ( $\mathrm{N} \mathrm{a} \mathrm{g} \mathrm{y,} \mathrm{1970).} \mathrm{Although} \mathrm{roe-deer,}$ like other ruminants, can maintain a constant level of nitrogen in the rumen for a certain time ( $\mathrm{Kl}$ e i $\mathrm{n} \& \mathrm{~S} \mathrm{ch}$ e $\mathrm{nh}$ e y d e $\mathrm{r}, 1970$ ), the way to ensure a sufficient protein level in food is to supplement their diet by herb layer plants, as being richer in protein and more digestible (Table 2; Le Resche \& Davis, 1973; Short, 1971; Urness et al., 1971; Perzanowski, 1978), or the distal parts of twigs. These components of the roe-deer's diet are more digestible and contain a higher percentage of protein than the other parts of new growth (C owan et al., 1970).

Dry matter digestibility of the food available for roe-deer in the deciduous tree stands of the Niepolomice Foreset exhibited very similar seasonal variation to that in the results obtained by American authors (U r n e s s, 1969; S hort, 1971). Young new-growth twigs have always been characterized by maximum, and ligneous leafless twigs by minimum, digestibility (Fig. 10). The digestibility of leaves and twigs in spring is very similar, but in autumn differs considerably (Fig. 12).

The effect of herb layer plants, containing more protein on the digestibility of twigs proved to be almost negligible (Fig. 14), but as some authors have suggested, certain components of diet with high protein content may contribute to an increase in digestibility by increasing the activity of rumen flora ( $\mathrm{Nagy}, 1970 ; \mathrm{Zi} \mathrm{ołe} \mathrm{cka,} \mathrm{1972;} \mathrm{Ch} \mathrm{u} \mathrm{ch}$, 
1974). Some plants, however, such as Artemisia tridentata, cause marked decrease in the digestibility of the whole diet by acting on the microorganisms of the rumen by mean of the essential oils contained in them ( $\mathrm{N}$ a g y et al., 1964; $\mathrm{N}$ a g y \& T e n g e r d y, 1968).

\subsection{Effect of the Composition of Food on its Consumption and Ability to Cover the Energetic Maintenance Expenditure of Roe-deer}

The considerable differences in seasonal voluntary food intake found in roe-deer (Fig. 2) were due to their being fed browse in varying degrees of phenological development (Fig. 1). The fact has been proved that voluntary intake by ruminants is considered as an important factor defining the quality of food consumed ( $\mathrm{H}$ e a n e y et al., 1968) and depends primarily on the digestibility of the given food (B l a x t e r, 1966). A large number of authors consider that it is not total digestibility, but the rate at which a ruminant utilizes food, which is the factor determining the amount consumed ( $\mathrm{Ma} \mathrm{utz} \& \mathrm{Petrides,1971;} \mathrm{Snider}$ \& Asplund, 1974). For this reason Snider \& Asplund (1974) examined, in addition to in vitro digestibility, so-called »organic matter solubility " $(O M S)$ of food samples, digesting them for half an hour in rumen fluid. These authors state that such evaluation gives a better description of the value of food of wild ruminants which, on account of the smaller rumen (2.5-6.8\% of body weight) in relation to domestic ruminants ( $13 \%$ of body weight) must prefer rapidly digestible food which is not retained for long in the rumen ( $\mathrm{Th}$ om a s et al., 1961). The smaller rumen, however, allows the animal to be more active and thus permits of satisfying food preferences to a greater degree.

Voluntary intake also depends on the chemical composition of food, particularly of fibre content or amount of cell wall, degree of lignification or incrustation with silica as plants lignified, particularly of branches (Van S o e st, 1965; Van S o e s t \& J o n e s, 1967; S h ort \& $\mathrm{R}$ e a g o r, 1970) and also on the amount of soluble carbohydrates ( $\mathrm{M} \mathrm{i-}$ ch ell, 1973).

The protein content in food also affects the consumption level of ruminants (Fig. 1). N a g y et al. (1969), who fed white-tailed deer on food differing as to fibre and protein contents, found that the animals preferred food with a higher protein content, despite the considerable amount of fibre in them. Since fibre was supplied in the form of cotton husks, and not browse, this is proof that not fibre content itself, but the physical character of food affects voluntary intake (L a redo \& M ins o n, 1973). 
The fact that ruminants prefer more digestible food richer in protein has been confirmed by a large number of research workers, who carried out analysis of samples of food consumed by animals with an esophageal fistula fitted (Van Dyne \& Torrel, 1964; Van Dyne \& Heady, 1965; Coleman \& Barth, 1973), or of rumen contents (Rice, 1970), or by direct observation of the animals' grazing (B e r g e r u d, 1970).

Many authors have shown (M on tg o m e r y \& B a u m g a r d t, 1965; A $\mathrm{mmann}$ et al., 1973), that food intake by ruminants increases with increasing nutrient value of the food to a level satisfying the animal's energy requirements. As the nutrient value of food increases, dry matter intake decreases and energy intake is maintained on a constant level. We did not find stabilization of food intake or reduction in food consumption in the relatively short experiments on digestion made in the present study, but constant increase in food was recorded as its nutrient value increased. A knowledge of the relation between food digestibility and its voluntary intake permitted of defining the minimum food digestibility which, under natural conditions, covers tne maintenance costs of roe-deer (Fig. 6).

Ull rey et al., (1970) estimated the daily maintenance expenditure of the white-tailed deer in winter as $131 \mathrm{kcal}$ of metabolic energy, $M E / \mathrm{kg}^{0.75}$, and W e in er (1977) on the basis of respirometric studies of roe-deer, as $150 \mathrm{kcal} M E / \mathrm{kg}^{0.75}$. Similarly $\mathrm{Th}$ o m p s o $\mathrm{n}$ et al. (1973) and $\mathrm{Holte} \mathrm{r}$ et al. (1977) estimate daily maintenance expenditure of the Odocoileus virginianus as from 150 to $160 \mathrm{kcal} M E / \mathrm{kg}^{0.75}$. Assuming that roe-deer have only browse available, since the deep snow cover prevents access to herb layer plants, the daily energy deficit, on account of the small browse consumption, would be at least $50 \mathrm{kcal}$ of digestible energy/ $\mathrm{kg}^{0.75}$ (D rożd ż \& $\mathrm{O}$ i e cki, 1973). The length of survival under such conditions would depend on the animal's store of energy and the weather conditions prevailing. It is clear from the relation between energy intake and food energy concentration (Fig. 7), and between dry matter digestibility and intake, that with digestible energy intake of $180 \mathrm{kcal}$, corresponding to about $150 \mathrm{kcal} M E / \mathrm{kg}^{0.75}$, (which may be compared with respiration), the roe-deer must have food available of minimum digestibility of $58 \%$ (Fig. 6). Such food should ensure $2.76 \mathrm{kcal}$ digestible energy, or $2.26 \mathrm{kcal}$ metabolizable energy, from 1 gramme of dry matter intake $(4.8 \mathrm{kcal} / \mathrm{g})$. With $58 \%$ browse digestibility, food intake was $64.2 \mathrm{~g} / \mathrm{kg}^{0.75}$ (Fig. 3) i.e. $150 \mathrm{kcal} / \mathrm{kg}^{0.75}$ (Fig. 6). Browse itself provides roe-deer with such food in summer (Fig. 2), but at other times of the year must be supplemented by herb layer plants. W e in e r (1977) estimates the digestibility making it possible to cover energetic main- 
tenance costs in roe-deer as $64 \%$. P e rzanowski (1978) has, however, shown that the herb layer should form over $50 \%$ dry matter of the roe-deer's daily food ration in winter. A $\mathrm{m} \mathrm{man} \mathrm{n}$ et al. (1973) consider that food with $50 \%$ digestibility i.e. $2.2 \mathrm{kcal} D E$ per 1 gramme of dry matter, is sufficient to ensure the energy balance of white-tailed deer.

In the case of cattle or sheep feeding, apart from the periods of gestation and lactation there is no need for foods, the total digestible nutrients of which (TDN) exceed 55\%, i.e. 2.42 digestible energy and 1.98 kcal metabolizable energy obtained from $1 \mathrm{~g}$ dry matter intake (C h u r ch, 1974).

When analyzing the results of in vitro digestibility of different species of trees and shrubs and certain herb layer plants (Table 1), no species with digestibility markedly exceeding $50 \%$ were found during winter in the present study. Similar results have been obtained by many American authors in analyzing the digestibility of browse and herb layer plants (Urness, 1969; Short \& R e a gor, 1970; Short, 1971; Segelquist et al., 1971; Ward, 1971; Snider \& Asplund, 1974). The effect of herb layer plants on digestibility of browse is also negligible (Fig. 14), and therefore in addition to preferences for more digestible food the roe-deer must cover its energy requirements by food of relatively low digestibility. It has been found that ruminants may consume, despite their identical digestibility, more leaves than, for instance, stems or twigs, and that the rate of passage of leaves or herb layer plants through the animals' alimentary tract is more rapid ( $\mathrm{L} \mathrm{a-}$ $\mathrm{r}$ e d o \& $\mathrm{M}$ in s o n, 1973). For example, the stems of grasses remain on an average $35 \%$ longer in the rumen than leaves. While retention of young new-growth twigs in the alimentary tract is about 20 hours, ligneous browse is retained about 40 hours or more ( $\mathrm{M} \mathrm{a} \mathrm{u} \mathrm{tz} \mathrm{\&} \mathrm{P} \mathrm{e} \mathrm{t} \mathrm{r} \mathrm{i-}$ $\mathrm{des}$, 1971). The roe-deer may therefore consume, in addition to food occupying over $50 \%$ of the rumen's capacity (S i u d a et al., 1969), a considerable amount of rapidly transported herb layer plants or leaves, not necessarily characterized by greater digestibility. Analyses of the rumen under-estimate the percentage of this quickly-digested fraction of the animal's diet by not allowing for its lesser retention and thus over-estimate the role of browse in ruminants' diet ( $\mathrm{G}$ a a $\mathrm{r}$ e et al., 1977). In feeding experiments roe-deer were observed to exhibit marked preference for leaves, or herb layer plants, as compared with leafless browse.

It would therefore appear that not only increase in the digestibility of its diet as a whole is the way to satisfy the roe-deer's energetic requirements, but also selection of foods, rapidly-digested and passing quickly through the alimentary tract.

In addition to the physical and chemical properties of food, seasonal 
changes in metabolism also affect intake in roe-deer and red deer. Particularly great fluctuations were observed between winter and the other seasons of the year. This is a phenomenon which has been found by very many research workers (Lochman et al., 1959; Verme \& Ull rey, 1974; Holter et al., 1977), which is connected with reduction in the metabolism of these animals in winter ( $\mathrm{Silver}$ et al., 1971; Weiner, 1977). Reduction in food intake during the winter months was also found by $\mathrm{M}$ i c h e ll (1973) in sheep feeding in pastures the whole year. It was due both to the decreasing nutrient value of the pasture herb layer and also to the decreasing energy requirements of sheep during this period ( $\mathrm{L}$ on s d a le \& T a y lor, 1970).

\subsection{Nutrient Value of the Roe-deer's Winter Food}

Analysis of the digestibility and chemical composition of the roe-deer's food showed that its nutrient value changes greatly over the course of a year. While the food supply in the summer months covers energy and protein requirements, both from the aspect of quantity and quality, the roe-deer's situation during a snowy winter becomes very difficult. Low temperature, limitation of access to herb layer plants owing to snow cover and decrease in activity (Borowski \& Kos a k, 1975) necessary to seek preferred food among that available, causes considerable loss in the roe-deer population during such periods ( $\mathrm{Pad}$ a ig a, 1968; B orowski \& Miłk owski; 1977).

The energy stores of deer are negligible in comparison with those of domestic ruminants, which renders the former even more dependent on habitat conditions ( $\mathrm{Nagy}$ et al., 1969) and the higher metabolism of these animals and the relatively smaller rumen make exacting demands in respect of quality on the food of roe-deer.

A knowledge of seasonal changes in the digestibility of different components of the roe-deer's food permits of evaluating available food in categories of digestible energy or digestible dry matter. Investigation of the relation between digestibility, chemical composition and voluntary food intake by roe-deer, on the other hand, permit of making an exhaustive estimate of the nutrient value of the food supply available to them.

The food accessible to roe-deer during summer in the deciduous tree stands of the Niepolomice Forest, in the form of browse, has been estimated by Bobek et al. (1975) as 20 ton dry matter/100 ha, i.e. 9.6 $\times 10^{7} \mathrm{kcal}$ gross. The average digestible energy of food for the summer period is as much as $70 \%$ (Fig. 2, Table 2), and may be considered as completely accessible to roe-deer. In winter, however, the supply of 
browse is about 5 tons of dry matter $/ 100$ ha, i.e. $2.4 \times 10^{7} \mathrm{kcal}$. Average digestibility of winter food does not exceed $40 \%$ (Fig. 2) and therefore digestible energy potentially available for use may be estimated as $9.6 \times 10^{3} \mathrm{kcal}$. While consumption is not limited in summer by digestibility level and, as already mentioned, can be considered as completely available for use, in winter daily consumption of food with $40 \%$ digestibility is about $45 \mathrm{~g} / \mathrm{kg}^{0.75}$ and does not fully satisfy the animal's energy requirements (Fig. 4). Such food needs supplementing by the more digestible herb layer plants, or plants not very digestible but characterised by low retention in the rumen (leaves, grass).

Analysis of the digestibility of the roe-deer's natural food over the yearly cycle shows that summer food is 1.75 times more digestible than in winter and its supply is 4 times greater in summer. Thus the food carrying capacity in summer is 7 times greater than in winter $(1.75 \times 4)$. The winter food supply will therefore depend not on the amount of browse, of which there is an excess even in winter, but on the possibility of supplementing it by more digestible food. It may be concluded that it is not the amount of food, but its digestibility, which determined the amount of the roe-deer's winter food supply.

Acknowledgements: The author wishes to convey his grateful thanks to the Management of the Institute of Zootechnics for making in possible for him to continue the studies begun at the Jagiellonian University, to Professor W. G r o$\mathrm{dzi}$ ński, Dr. M. Gębczýnski and Dr. A. Górecki for their critical remarks and to Mrs. M. K a w u la for technical assistance with the work involved.

\section{REFERENCES}

1. Ammann A. P., Cowan R. L., Mothershead C. L. \& Baumg a rdt B. R., 1973: Dry matter and energy intake in relation to digestibility in white-tailed deer. J. Wildl. Manage., 37: 195-201.

2. Associations of Official Agricultural Chemist, 1960: Official methods of analysis. 9th ed. 832 pp. Washington, D.C.

3. B a ker A. J., 1973: Effect of lignin on the in vitro digestibility of wood pulp. J. Anim. Sci., 36: 768-771.

4. Barnes R. F., 1965: Use of in vitro rumen fermentation technique for estimating forage digestibility and intake. Agron. J., 57: 213-216.

5. B ergerud A. T., 1970: Food habits of hand-reared caribou Rangifer tarandus L. in Newfoundland. Oikos, 21: 348-350.

6. Bobek B., Weiner J. \& Zieliński J., 1972: Food supply and its consumption by deer in a deciduous forest of Southern Poland. Acta thericl., 17: $182-202$.

7. Bobek B., Drożd ż A., Grodziński W. \& Weiner J., 1974: Studies on productivity of the roe-deer population in Poland. Proc. XIth Int. Congr Game Biol.: 115-123. Liber Tryck, Stockholm. 
8. Bobek B., Perzanowski K., Sajdak G. \& Szulakowska G., 1974: Seasonal changes in quality and quantity of deer browse in a deciduous forest. Proc. XIth Int. Congr. Game Biol.; 545-552. Liber Tryck, Stockholm.

9. Bobek B., Borowski S. \& Dzięciołowski R., 1975: Browse supply in various forest ecosystems. [In: "The role of large herbivore mammals in woodland ecosystems", eds Grodziński W. \& Pucek Z.]. Pol. ecol. Stud., 1: $17-32$.

10. Bobek B., Perzanowski K., Siwanowicz J. \& Zieliński J., 1978: Deer pressure on forage in a deciduous forest. Oikos (in press).

11. Borowski S. \& Kossak S., 1975: The food habits of deer in Bialowieża Primeval Forest. Acta theriol., 20: 463-506.

12. Borowski S. \& Miłkowski L., 1977: Beobachtungen zum Schalenwild in der Bialowieżaheide in den Jahren 1969-1973. Z. Jagdwiss., 23: 169-187.

13. B la xter K. L., 1966: Przemiany energetyczne u przeżuwaczy. Państw. Wyd. Roln. Leśne: 1-379. Warszawa.

14. Church D. C., 1974: Digestive physiology and nutrition of ruminants. Albany Printing Co., 3: 1-351. Albany, Oregon.

15. Coleman S. W. \& Barth K. M., 1973: Quality of diets selected by grazing animals and its relation to quality of available forage and species composition of pastures. J. Anim. Sci., 36: 754-761.

16. Cowan R. L., Jordan J. S., Grimes J. L. \& Gill J. D., 1970: Comparative nutritive value of forage species. [In: "Range and Wildlife Habitat Evaluation«]. U.S.D.A. publ. no. 1147: 48-56. Flagstaff \& Tempe, Arizona.

17. Drożd $\dot{z}$ A. \& Osiecki A., 1973: Intake and digestibility of natural foods by roe-deer. Acta theriol., 18: $81-91$.

18. Drożd ż A., W e iner J., Gębczyńska Z. \& Krasińska M., 1975: Some bioenergetics parameters of wild ruminants. [In: "The role of large herbivore mammals in woodland ecosystems", eds Grodziński W. \& Pucek Z.]. Pol. ecol. Stud., 1: 85-101.

19. Dzięciołowski R., 1970: Pojemność wyżywieniowa środowisk leśnych jako problem ekologiczny. Sylwan, 11: 1-17.

20. Dzięciolowski R., 1970: Food of the red deer as determined by rumen content analyses. Acta theriol., 15: 89-110.

21. Gaare E., Sörensen A. \& White R. G., 1978: Are rumen samples representative of the diet? Oikos, 29: 390-395.

22. Grodzinski W., 1975: The role of large herbivore mammals in functioning of forest ecosystems - a general model. [In: "The role of large herbivore mammals in woodland ecosystems", eds Grodziński W. \& Pucek Z.]. Pol. ecol. Stud., 1: 5-15.

23. Grodziński W. \& Pucek Z., 1975: The role of large herbivore mammals in woodland ecosystems. Polish ecol. Studies, 1: 1-142.

24. Heaney D. P., Pritchard G. I. \& Pidgen W. J., 1968: Variability in ad libitum forages intake by sheep. J. Anim. Sci., 27: 159-164.

25. Holter J. B., Urban W. E. \& Hayes H. H., 1977: Niutrition of northern white-tailed deer throughout the year. J. Anim. Sci. 45: 365-376.

26. J os hi D. C., 1973: Different measures in the prediction of the nutritive value of forages. Acta Agric. scand., 22: 243-247.

27. Klein D. R. \& Schonheyder F., 1970: Variation in ruminal nitrogen levels among some Cervidae. Can. J. Zool., 48: 1137-1442. 
28. L a r edo M. A. \& Minson D. J., 1973: The voluntary intake, digestibility and retention time by sheep of leaf and stem fractions of five grasses. Austr. J. agric. Res., 24: 875-888.

29. Le Resche R. E. \& Davis J. L., 1973: Importance of nonbrowse foods to moose on the Kenai Peninnsula, Alaska. J. Wildl. Manage. 37: 279-287.

30. Lochman J., Tvrdikova A. \& Melichárova A., 1961: Spotřeba živin u srnci zvere (Capreolus capreolus L.). Lesnictví, 7: 551-570.

31. Lonsdale C. R. \& Taylor J. C., 1970: Conserved forages. Effect of species variety, stage of growth, method of preservarion, processing and feeding. Grass. Res. Inst. Ann. Rep.: 77-82. London.

32. Lowrey R. S., Burton G. W., Johnson J. C. \& Marchant W. H., 1968: In vivo studies with coast-cross 1 and other bermudas. Georgia Agr. Exp. Sta. Res., Bull. 55: 22-35.

33. Lusk J. W., Browing C. B. \& Miles J. T., 1962: Small sample in vivo cellulose digestion procedure for forage evaluation. J. Dairy Sci., 45: 69-78.

34. M a u tz W. W., 1971: Confinement effect on dry-matter digestibility coefficients displayed by deer. J. Wildl. Manage., 35: 366-368.

35. Mautz W. W. \& Petrides G. A., 1971: Food passage rate in the whitetailed deer. J. Wild1. Manage., 35: 723-731.

36. Meyer R. M., Bartley E. E., Julius F. \& Fina L. R., 1971: Comparison of four in vitro methods for predicting in vivo digestibility of forages. J. Anim. Sci., 32: 48-62.

37. Michel1 P. J., 1973: Digestibility and voluntary intake measurements on regrowth of six Tasmanian pasture species. Aust. J. Exp. Agr. Anim. Husb., 13: $158-164$.

38. Mi chell P. J., 1973: Relations between fibre and water soluble carbohydrate contents of pasture species and their digestibility and voluntary intake by sheep. Aust. J. Exp. Agr. Anim. Husb., 13: 165-170.

39. Millet M. A., Baker A. J., Feist W. C. \& Mellenberger R. W., 1970: Modifying wood to increase its in vitro digestibility. J. Anim. Sci., 31: $781-788$.

40. Monson W. G., Lowrey R. S. \& Forbes I. Jr., 1969: In vivo bag vs. two-stage in vitro digestion: comparison of two techniques for estimating drymatter digestibility of forages. Agron. J., 60: 610-612.

41. Montgomery W. J. \& B a umgardt B. R., 1965: Regulation of food intake in ruminants. 1. Pelleted rations varying in energy concentrations. J. Dairy Sci., 48: $569-574$.

42. Morris M. J. \& Kovner J. L., 1970: Forage quality and animal production: some statistical problems. [In: "Range and Wildlife Habitat Evaluation«]. U.S.D.A. publ. no. 1147: 32-35. Flagstaff \& Tempe, Arizona.

43. Nagy J. G., Stein hoff P. M. \& Ward L. A., 1964: Effects of essential oils of sagebrush on deer rumen microbial function. J. Wild. Manage., 28: $785-790$.

44. N a g y J. G., 1970: Biological relations of rumen flora and fauna. [In: "Range and Wildlife Habitat Evaluation«]. U.S.D.A. publ. no. 1147: 159-163. Flagstaff \& Tempe, Arizona.

45. Nagy J. G. \& Tengerdy F. M., 1978: Antibacterial action of essential oils of Artemisia as an ecological factor. Appl. Microbiol., 16: 441-444.

46. Nagy J. G., Hakons on T. \& $\mathrm{Knox}$ K. L., 1969: Effect of quality on food intake in deer. Trans. Thirty-Fourth North Am. Wildl. Nat. Res.: 146-154. 
47. N e a thery M. W., 1969: Dry matter dissappearance of roughages in nylon bags suspended in the rumen. J. Dairy Sci., 52: 74-85.

48. Neathery M. W., 1972: Conventional digestion trials vs. nylon bag technique for determining seasonal difference in quality of midland bermudagrass forage. J. Anim. Sci., 34: 1075-1084.

49. New some J. D., Short H. L., Fowler J. F. \& M c Coy G. L., 1968: Study shows effect of nutrition on growth of deer. Luisiana Agriculture, 12: 4-5.

50. Nordan H. C., Cowan I. Mct. \& Wood A. J., 1968: Nutritional requirements and growth of black-tailed deer (Odocoileus hemionus columbianus) in captivity. Symp. zool. Soc. London, 21: 89-96.

51. Nordan M. C., Cowan I. McT. \& Wood A. J., 1970: The feed intake and heat production of the young black-tailed deer (Odocoileus hemionus columbianus). Can. J. Zool., 48: 275-282.

52. Pa d a ig a W. I., 1968: Permissible density of roes in Lithuania forest. Lesovedenije, 2: 60-67 [In Russian with English summ.].

53. Perzanowski K., 1978: The effect of winter food composition on roe-deer budget. Acta theriol., 23, 31: 451-467.

54. Pi etrzak H., 1974: Konsumpcja i strawność naturalnych pokarmów u sarn. MSc. thesis, Jagiellonian Univ.: 1-21.

55. Pi otrowski J., 1974: Niektóre aspekty zmienności wyników uzyskiwanych przy oznaczaniu strawności pasz metodą ,in vitro”. Rozpr. habil., 7: 1-55. Inst. Genet. Hod. Zwierząt PAN, Jastrzębiec.

56. R ic e R. W., 1970: Stomach content analyses: A comparison of the rumen vs. esophageal technique. [In: "Range and Wildlife Habitat Evaluation«]. U.S.D.A. publ. no 1147: 127-132. Flagstaff \& Tempe, Arizona.

57. Saunders R. M., Connor M. A., Both A. N., Bickoff E. M. \& Kohler G. O., 1973: Measurement of digestibility of alfalfa protein concentrates in vitro and in vivo methods. J. Nutr., 103: 530-535.

58. S chwartz C. C. \& Nag y J. G., 1972: Maintaining deer rumen fluid for in vitro digestion studies. J. Wildl. Manage., 36: 1341-1343.

59. Short H. L., 1966: Methods for evaluating forages for wild ruminants. Trans. Thirty-First North Am. Wildl. Natur. Res. Conf., 14: 122-128.

60. Short H. L., 1970: Digestibility trials: in vivo technique. [In: „Range and Wildlife Habitat Evaluation«]. U.S.D.A. publ. no 1147: 79-84.

61. Short H. L., 1971: Forage digestibility and diet of deer on southern upland range. J. Wildl. Manage., 35: 698-706.

62. Short H. L., Dietz D. R. \& Remmenga E. E., 1966: Selected nutrients in mule deer browse plants. Ecology, 47: 222-229.

63. Short H. L. \& R e gor J. C., 1970: Cell wall digestibility affects forage value of woody twigs. J. Wildl. Manage., 43: 964-967.

64. Short H. L. \& Harrel A., 1969: Nutrient analysis of two browse species. J. Range Manage., 22: 40-43.

65. Short H. L., B lair R. M. \& Epps E. A. Jr., 1973: Estimated digestibility of some southern browse tissues. J. Anim. Sci., 36: 964-967.

66. Segelquist Ch. A., Mitch R. \& W a rd F. D., 1971: Quantity and quality of Japanese honey suckle on Arkansas Ozark food plots. Proc. 25th Ann. Conf. South. Ass. Game \& Fish Comiss.: 47-53.

67. Silver H., Holter J. B., Colovos N. F. \& H a yes H. H., 1971: Effect of falling temperature on heat production in fasting white-tailed deer. J. Wildl. Manage., 35: 37-46. 
68. Siuda A., Zurowski W. \& Siuda H., 1969: The food of roe deer. Acta theriol., 15: 247-262.

69. Snider C. C. \& A s plund J. M., 1974: In vitro digestibility of deer foods from the Missouri Ozarks. J. Wildl. Manage., 38: 20-31.

70. Thom a s J. W., Ingalls J. R., Young M. \& Reddy B. S., 1961: Effect of ad libitum or equalized feeding of alfalfa hay or silage on rumen contents and its characteristics. J. Dairy Sci., 44: 1203-1208.

71. Thompson C. B., Holter H. H., Hayes H. H., Silver H. \& U r ban W. E., 1973: Nutrition of white-tailed deer. I. Energy requirements of fawns. J. Wildl. Manage., 37: 301-308.

72 Tilley J. M. A. \& Terry R. A., 1963: A two-stage technique for the in vitro digestion of forage crops. J. Br. Gras. Soc., 18: 104-111.

73, Ulirey D. E., Youatt W. G., Johnson H. E., Fay L. D. \& Bradley B. L., 1967: Protein requirement of white-tailed deer fawns. J. Wildl. Manage., 31: 679-685.

74. Ullrey D. E. Youat t W. G., Johnson H. E., Fay L. D., Shoepke B. L. \& M a gee W. T., 1970: Digestible and metabolizable energy requirements for winter maintenance of Michigan white-tailed does. J. Wildl. Manage., 34: $863-869$.

75. Urness P. J., 1969: Nutritional analyses and in vitro digestibility of mistletoes browsed by deer in Arizona. J. Wildl. Manage., 33: 449-505.

76. Urness P. J., Green W. \& Watkins R. K., 1971: Nutrient intake of deer in Arizona chapparal and desert habits. J. Wildl. Manage., 35: 469-475.

77. Wallace J. D. \& Van Dyne G. M., 1970: Precision of indirect method: for estimating digestibility of forage consumed by grazing cattle. J. Range Manage., 23: 424-430.

78. Ward L. A., 1971: In vitro digestibility of elk winter forage in southern Wyoming. J. Wildl. Manage., 35: 681-688.

79. W e in e r J., 1977: Energy metabolism of the roe-deer. Acta theriol., 22: 3-24.

80. Van Dyne G. M. \& Torrel D. T., 1964: Development and use of the esophageal fistula. A review. J. Range Manage., 17: 7-12.

81. Van Dyne G. M. \& Heady H. F., 1965: Interrelations of botanical and chemical dietary components of animals grazing dry annual range. J. Anim. Sci., 24: 305-311.

82. Van Keuren R. W. \& Heineman W. W., 1962: Study of a nylon bag technique for in vivo estimation of forage digestibility. J. Anim. Sci., 21: 340346.

83. Van Soest P. J., 1965: Factors infuencing the voluntary intake to chemical composition and digestibility. J. Anim. Sci., 24: 834-843.

84. Van Soest P. J. \& Jones L. H. P., 1967: The effect of silica on forages upon digestibility decline. J. Anim. Sci., 24: 119-128.

85. Verme L. J. \& Ullrey D. E., 1974: Feeding and nutrition of deer. [In: "Digestive Physiology and Nutrition of Ruminants", ed. D. C. Church]. Albany Printing Co.: 275-291. Albany, Oregon.

86. Zi ołecka A., 1969: Badania nad oznaczaniem strawności u przeżuwaczy. Rocz. Nauk. rol., D, 127: 1-153.

87. Z i ołecka A., 1972: Ocena wartości pokarmowej zielonek, ze szczególnym uwzględnieniem pastwiska. Przegl. nauk. Lit. zoot., 17: 11-37. 
Andrzej DROŻDż

STRAWNOSC I POBRANIE NATURALNEGO POKARMU PRZEZ SARNY

\section{Streszczenie}

1. Oceniono sezonową konsumpcję i strawność in vivo naturalnego pokarmu przez. sarny (Capreolus capreolus $\mathrm{L}$ in n a e u s, 1758) oraz metodą in vitro i woreczków nylonowych strawność dominujących gatunków roślin runa i żeru pędowego ścinanego co miesiąc w lasach liściastych Puszczy Niepołomickiej koło Krakowa.

2. Analizy chemiczne wykazały zmniejszanie się zawartości wody w żerze pędowym w sezonie wegetacyjnym od $76 \% \mathrm{w}$ maju do $42 \% \mathrm{w}$ miesiącach zimowych. Zawartość białka również była najwyższa wiosną $(22 \%)$, najniższa zimą $(6-7 \%)$, natomiast poziom włókna wzrastał od $13,9 \%$ na wiosnę do $40 \% \mathrm{w}$ zimie (Fig. 1).

3. Konsumpcja suchej masy żeru pędowego (DMI) wahała się od około $450 \mathrm{~g}$ w zimie tj. 40 -50 g s.m. $/ \mathrm{kg}^{0.75}$ do $700 \mathrm{~g} \mathrm{w}$ lecie $-80 \mathrm{~g}$ s.m. $/ \mathrm{kg}^{0.75}$ na dobe (Fig. 2) i zależała od strawności paszy $D M I=1,60+1,08$ DMD i zawartości wlókna (F), $D M I=102,07-1,73 \mathrm{~F}$ (Fig. 3. Fig. 9).

4. Strawność żeru pędowego zależała od jego fenologicznego rozwoju i była najwyższa wiosną - 73,3\%, latem wyniosła średnio 55-58\% i zimą prawie $40 \%$ (Fig. 10 B). Stwierdzono ujemną korelację między zawartością włókna a strawnością paszy $D M D=89,64-1,51 F$ (Fig. 11) i dodatnią dla białka $D M D=23,69+2,31$ PC.

5. Strawność substancji organicznej $(O M D)$ była niższa od strawności suchej masy wg. równania: $O M D=4,54+0,974 D M D$.

6. Strawność in vitro wg metody Tilleya i Terryego żeru pędowego dominujących 12 gatunków drzew i krzewów (Alnus glutinosa, Betula verrucosa, Carpinus betulus, Frangula alnus, Fraxinus excelsior, Populus tremula, Quercus robur, Rubus sp., Rubus idaeus, Salix caprea, Tilia cordata, Sambucus nigra) wyniosła średnio w maju $64,4 \%$, w czerwcu była niższa o $11 \%$, w lecie obniżała się o dalsze $10 \%$ wynosząc w październiku po opadnięciu liści 43,1\% (Fig. 10). Odmienną charakterystykę posiadały czarny bez, kruszyna i jesion, których przyrosty byly $w$ lecie i $w$ jesieni bardziej strawne, niż pozostałych 9 badanych gatunków (Fig. 10). Liście drzew i krzewów posiadały wyższą strawność in vitro niż pędy, a ich strawność w sezonie wegetacyjnym obniżała się wolniej niż pędów (Fig. 12, 13). Strawność in vitro roślin runa przez cały sezon wegetacyjny była wyższa niż żeru pędowego (Tab. 1). Stwierdzono, że średnia strawność roślin runa w uprawach zmniejsza się szybciej w ciągu lata, niż w młodniku, czy starodrzewiu (Tab. 2).

7. Strawność próbek żeru pędowego w woreczkach nylonowych wkładanych z próbkami do żwacza przetokowanej owcy była skorelowana z strawnością uzyskaną metodą in vitro, chociaż od maja do września była wyźsza od strawności in vitro o 5\%. Proces odwrotny mial miejsce $w$ jesieni $\mathrm{i} w$ zimie, gdzie wyniki uzyskane metodą woreczków nylonowych byly niższe o 4,5\% od wyników uzyskanych metodą in vitro.

8. Wyniki badania strawności in vitro diet mieszanych (roślin runa i żeru pędowego) nie wykazały istotnego wpływu roślin runa na strawność żeru pędowego (Fig. 15).

9. Porównując strawność suchej masy metodą in vitro (IVDMD) z in vivo (DMD) tych samych diet, stwierdzono wysoką korelację między obydwoma metodami $(r=0,980) \quad D M D=2,16+1,03$ IVDMD. Na podstawie zależności między strawnościa: 
pokarmu a jego pobraniem dowoli (Fig. 6) wyprowadzono równanie pozwalające na ocenę poziomu konsumpcji pokarmu przez sarny o znanej strawności in vitro: $D M I=9,07+0,927$ IVDMD.

10. Stwierdzono, że do zabezpieczenia energetycznych kosztów utrzymania sarn niezbędny jest pokarm o strawności minimum 58\% (Fig. 6) zapewniający z 1 grama suchej masy 2,76 kcal energii strawnej. W zimie sam żer pędowy $\mathrm{z}$ uwagi na niską strawność i pobranie jest pokarmem wymagającym uzupełnienia go bardziej strawnymi i szybciej przechodzącymi przez przewód pokarmowy roślinami runa, ewentualnie liśćmi drzew, czy krzewów.

11. W badanym terenie strawność żeru pędowego dostępnego dla sarn jest $w$ lecie 1,75 razy wyższa niż $w$ zimie a jego zasobność pokarmowa $w$ grądzie Puszczy Niepołomickiej jest 7 razy większa w lecie.

12. Baza pokarmowa jeleniowatych zależy nie od ilości żeru pędowego, którego nawet $w$ zimie jest dla sarn pewien nadmiar, ale od jego strawności i możliwości uzupełnienia go karmą łatwostrawną. Wysiłki gospodarki łowieckiej powinny zmierzać w kierunku poprawy zimowej bazy żerowej sarn przez wprowadzanie zabiegów takich, jak prześwietlające cięcia poprawiające warunki wzrostu roślin runa, zakładanie poletek żerowych a nawet sadzenie gatunków preferowanych przez sarny, zapobiegajacych zgryzaniu gatunków cennych gospodarczo. 